\title{
PARA ONDE VAI A HISTÓRIA DA
}

ARTE?

GRISELDA POLLOCK
WHITHER ART HISTORY?

¿ HACIA DÓNDE VA LA HISTORIA DEL ARTE? 
Há aflição no mundo liquefeito da consciência modernista.

*Universidade de São Paulo (USP), Brasil

https://doi.org/10.11606/ issn.2178-0447. ars.2021.191637

1. Texto originalmente publicado em The Art Bulletin (março 2014, vol. $96, n^{\circ} 1$, pp. 9-23) no âmbito de iniciativa editorial que propôs, no centenário da publicação, o tema "Para onde aponta a história da arte?" [Whither Art History?], atraindo para 0 debate uma constelação numerosa e diversificada de autores entre $2013 \mathrm{e}$ 2016. Em março de 2012 a revista anunciou que passaria a publicar a partir daquele primeiro número do ano uma série de matérias dedicadas ao exame da história da arte, em comemoração ao centenário que ocorreria em 2013. Desde então e até 2016, Art Bulletin traria três seções:

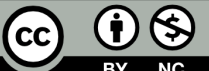

que precisamos estar sempre indo a algum lugar. Se pergunParece que precisamos estar sempre indo a algum lugar. Se perguntamos "Para onde vai a história da arte?", fica pressuposto que ou estamos indo a algum lugar (bom), ou deixando de fazê-lo (mau). Talvez haja o pensamento implícito de que nos perdemos e agora precisamos buscar uma nova direção, ou de que o caminho que estávamos trilhando não era bom para nós. Será que a tradição nos acena? Será que a reconsolidação é um retrocesso em face de desafios recentes? Enfim, estamos numa paralisia ou numa encruzilhada? O que quer que seja, a questão, em si mesma, sugere uma pressão formidável para nos dirigirmos a algum lugar e fazermos algo novo.

Em março de 2012, apresentei uma palestra no simpósio intitulado "Depois da nova História da Arte" ["After the New Art History"] (POLLOCK, 2012a). Particularmente, eu recusava a falsa categoria "nova História da Arte" ["new art history"], rejeitando a ideia de que o que quer que estivesse sendo designado dessa maneira pudesse trazer algo de novo. A referida "nova História da Arte”, fos- 
"Regarding Art and Art History"

["A propósito da arte e

da História da arte"] (que

às vezes levou o título

"Whither Art History?"), uma

seção intitulada "Notes from the Field" ["Comentários do campo"] e a terceira, nomeada "Interview", de conversas/entrevistas sobre questões do campo.

2. A seleção do conjunto de títulos apresentados aqui pela primeira vez em versão brasileira resultou das discussões do grupo de estudantes, assistentes editoriais e editoras que organiza este número especial de Ars, e que transcorreram num período de cerca de um ano e meio, antecedendo o lançamento desta edição; a iniciativa visa ampliar o acesso dos pesquisadores brasileiros, estudantes de graduação e pós-graduação a autores que marcaram posição relevante num debate que renovou radicalmente 0 campo disciplinar da história da arte nas últimas décadas. Agradecemos à autora $a$ autorização para tradução e republicação do texto. se o que fosse, teria seu valor não por ser nova, mas por se demonstrar crítica, engajada, historicamente fundada, nutrida pelas vozes emergentes de públicos até então excluídos e enriquecida pela participação em reorientações tremendamente significativas do pensamento e da prática nas humanidades, em geral. Do mesmo modo, a compulsão por suplantar - ser o novo no lugar do velho novo, codificada sob o termo "depois" - pareceu-me implicitamente morta" O que é apresentado como "velho" pode ser descartado como exaurido, fora de moda, a ser substituído. Claramente, o contexto mais amplo daquilo que o eminente sociólogo Zygmunt Bauman (2001) diagnostica como a condição de nossos tempos - a modernidade líquida - mostra-se vigente em nosso campo.

De acordo com a análise de Bauman sobre nossa situação presente, sob o capitalismo global, a modernidade líquida identifica uma modernização (mudança) compulsiva em nome da própria modernização (mudança). Conforme o autor argumenta, havia, outrora, uma ideologia ou um ideal lastreando o progresso; a modernização desestabilizava o passado petrificado para instalar uma nova ordem. Ela tinha um telos, transformar o velho no novo. Hoje, tudo indica, não há uma destinação imaginada. A moda, sozinha, comanda a necessidade da novidade constante de mercadorias, 
corpos, relações e "viradas" intelectuais, tudo o que torna obsoleta qualquer coisa ou ideia no momento mesmo de seu aparecimento. Dessa maneira, ser constante passa a ser fora de moda, com a consequente perda da possibilidade de uma política da história.

A ideia do novo, dessa maneira, cria o que se transforma no velho. Há fantasias psicológicas de superação edípica (filhos tomando o lugar de pais), como também operações sociológicas de deslocamento geracional envolvidas nessa miragem de posteridade compulsiva. Em paralelo a essa tendência, surgem declarações, ora da morte do feminismo, ora do fenecimento deste sob o pós-feminismo, ora, ainda, do engolfamento da segunda pela terceira ou quarta onda, todas essas declarações compartilhando o "ter vindo depois" compulsório e se dissipando muito antes que se tenha consumado algum esforço sério de compreensão do impacto, da ressonância ou do significado de qualquer intervenção feminista.

Não acredito estar indo a parte alguma nem pretendo que a História da Arte [Art History] ou o feminismo se ponham em direções "novéis" em nome da busca do novo (ao longo deste texto deverei usar o termo "História da Arte" [Art History] para designar a disciplina e distingui-la de seu campo, a história da arte [History of $A r t]^{2}$ : uma distinção conceitual disponível em língua inglesa). Não 
se trata de sugerir uma complacência desafiadora, uma recusa em responder a forças históricas imprevistas, necessariamente atestando mudanças em nossas práticas e métodos de pensar. Por um lado, estou argumentando que será necessário um longo período até que se possa absorver completamente as iniciativas que buscaram dar nova forma aos estudos em História da Arte no final do século XX. Para fazermos justiça a eles, devemos desafiar as deturpações incitadas pela mentalidade brutal da "morte-ao-passado", porquanto tais distorções tornam invisível aquilo que poderíamos chamar de o necessário enfrentamento do acontecimento - em si mesmo traumático, com seu choque para o sistema - com suas contradições e potencialidades que perseveram como um projeto crítico e emancipador ${ }^{3}$. Por outro lado, não lograremos atinar com o que de fato ocorreu se falharmos em entender as trocas complexas entre todo tipo de prática do pensar e as condições históricas e sociais que determinam essas práticas, de modo complacente ou oferecendolhes resistência. O que se torna urgente pensar hoje ou, melhor, o que pode nos desafiar a uma resistência hoje não é algo interno à formação intelectual ou à disciplina História da Arte. As questões que confrontamos como historiadores da arte brotam no mundo; as práticas da arte e aquelas práticas que constituem sua mais ampla 
moldura, institucionalização e análise, tanto registram o que acontece no mundo como também nos desafiam, como especialistas e pensadores, a discernir os engajamentos genuinamente críticos, atentos, e não meramente responsivos em sua transformação em [in] arte contemporânea, ou rumando à [into] arte contemporânea. Insular o problema no interior do mundo da academia ou do museu trai tanto a visão simplista da arte e seus discursos como índices da refração da história pela cultura quanto a visão mais complexa do sério enfrentamento levado a cabo pela arte daquilo que a ilumina e lhe empresta seus materiais, impactos e desafios.

Se nos dizem que devemos encontrar um novo rumo porque nos vemos hoje perdidos numa névoa de confusão teórica e possibilidades metodológicas que competem entre si, talvez se trate de uma boa ocasião para mostrarmos certa dose de fidelidade intelectual às ricas fundações do pensamento e das práticas críticas produzidas em meio aos estimulantes desenvolvimentos na História da Arte como também na arte, ao longo do último meio século. Faríamos bem em nos demorarmos mais em qualquer uma das paragens pontilhando essa paisagem hoje complexa. Em vez de nos forçarmos a seguir o passo ou a nos recolhermos detrás dos portões fortificados que do passado tentam ignorar os desafios das Histórias da Arte recentes, 
viajemos por essa paisagem, mas sem os maus guias de viagem que tornam anacrônico o passado e fornecem apenas rotas limitadas aos pontos selecionados, ao mesmo tempo que demovem nos visitantes $o$ encontro com outras rotas possíveis.

Um problema central é o gesto histórico que fundou nossa disciplina. Ele era, claro, profundamente paradoxal. Para que uma História da Arte emergisse (como formação intelectual), a arte como arte teve de descobrir que tinha uma história (em vez de ser um problema atemporal da estética filosófica ou da norma acadêmica). O formular uma disciplina a fim de estudar a dimensão histórica específica da arte - uma arte detentora de substância singular que tanto atravessa o tempo quanto é mudada por ele - progressivamente separou a arte da história tomada em seu sentido mais amplo e a partir do campo ampliado da história da cultura e do pensamento humanista no qual ela havia sido um espetáculo lateral. A disciplina História da Arte fabrica uma história separada para a arte como uma sucessão formal de estilos, iconografias variáveis, movimentos autodefinidos, períodos e instituições (por exemplo: a formação do artista, o mecenato, o modo de expor a arte, o comércio, as coleções). Embora valiosa, em certo sentido, a tendência a esse isolamento alcançou sua forma mais extrema no momento em 
que pensar historicamente sobre quaisquer práticas artísticas era tido como algo contrário à História da Arte; tal campo apenas poderia ser articulado mediante sua qualificação como história social da arte. $\mathrm{O}$ que sugeria a estranha possibilidade de que alguma história pudesse não ser social. Atuando no campo como uma intelectual feminista, eu me deparei com o fato curioso de que minhas referências a questões sociais, culturais ou históricas, tais como sexualidade ou gênero, não eram consideradas parte da História da Arte, sendo rotuladas, em vez disso, de fatores sociológicos essencialmente extrínsecos ou, pior, extrínsecos à história da arte 4 . Encontramos aí um dos problemas na formulação da questão no singular, como "História da Arte" [art history], em vez dos meus neologismos preferidos, "as histórias da arte" ["the histories of art”] (1988) ou as "Histórias da Arte" ["art's histories"] (1996). Ofereço, a seguir, três pontos de acesso inusuais a essa discussão.

\section{UM PONTO DE PARTIDA LOCAL}

Acabo de concluir uma tarefa algo extraordinária. Encomendaram-me compilar uma pesquisa bibliográfica sobre "mulheres e História da Arte" (já uma categoria confusa - mulheres na história 
da arte, mulheres na disciplina História da Arte, gênero e arte?), tendo sido fixado o limite de 8 ooo palavras para tanto. Como meu texto final atingiu 38 ooo palavras, com lacunas consideráveis resultando da parcialidade de minha própria perspectiva no cômputo total desse campo massivo, um (uma) parecerista demonstrou irritação em face de uma seção específica que eu havia acrescentado, considerada "inusual” por ele ou ela. A seção tratava de feminismo e Aby Warburg. Posso entender que estamos, aqui, longe da História da Arte mainstream. Tampouco se trata do que geralmente se entende pela vertente-chave das Histórias da Arte feministas no cenário norte-americano. Ainda assim, já houve muitas feministas na América Latina e na Europa envolvidas de longa data com o legado de Warburg. O texto fundante dessa vertente é o da historiadora da arte alemã Sigrid Schade (1983). Durante os anos finais da década de 1970, Schade voltou-se à Biblioteca do Instituto Warburg, em Londres, como o único lugar no qual ela poderia explorar a irrupção inquietante da queima de bruxas, com suas inscrições visuais e incitamentos concomitantes, no princípio do período moderno: como tal violência brutal e misógina poderia acompanhar aquilo que o pensamento histórico aponta como o início do período moderno e um Renascimento da cultura humanista? Não se alojando em qualquer 
período que a consciência moderna ocidental pudesse consignar à alteridade e ao primitivismo, essas investidas contra as mulheres no século XVI e no princípio do século XVII e suas vívidas refrações culturais haveriam de ser confrontadas ao mesmo tempo como sintomas de uma emergente arte "moderna", e em relação ao ressurgimento, no período, de conflitos mais profundos que produziam violência tanto simbólica quanto real. Como tal paradoxo poderia fazer sentido? Schade acompanhou a rejeição warburguiana dos mitos dominantes da História da Arte que seguem no rastro de um progresso contínuo e propõem a modernidade como uma destinação inquestionavelmente progressiva.

Durante um simpósio convocado por Judith Rodenbeck no Clark Art Institute, intitulado "O feminismo após as ondas" [Feminism after the Waves], em maio de 2012, Jaleh Mansoor, uma historiadora da arte mais jovem, introduziu-me ao trabalho de Silvia Federici, feminista italiana especializada em teoria política, e a seu livro Calibã e a bruxa: mulheres, corpo e acumulação primtiva [Caliban and the Witch: Women, the Body and Primitive Accumulation] (FEDERICI, 2017). Como historiadora, Federici atravessa um território histórico similar àquele coberto por Schade, para defender que a desapropriação violenta das mulheres - isto é, sua domesticação for- 
çada, a exclusão de seu trabalho do sistema de troca e a reconfiguração de seus serviços em cuidados de adultos e crianças posta como natural - foi fundante para a acumulação primitiva, da qual dependeu a emergência do primeiro capitalismo. Em vez de entregar-se a especulações abstratas sobre como marxismo e feminismo poderiam se "casar”, Federici apresentou uma declarada guerra de gêneros e, dessa maneira, a própria exploração fundada no gênero como base do novo sistema econômico que moldaria o mundo moderno. A queima de bruxas era parte da violência com a qual o novo sistema se imporia. Do ponto de vista ideológico, ela forçava a uma nova definição da condição feminina, específica do novo sistema socioeconômico5 ${ }^{5}$ Tal conceito da condição feminina poderia, entretanto, ser representado como "natural" (em vez de ser imposto mediante o uso de violência) apenas pondo-se a si mesmo contra o seu oposto, o rebelde monstruoso, a bruxa. Federici compara a função da bruxa ao Calibã da ficção, que por sua vez foi interpretado como uma projeção do Outro, na retórica igualmente violenta do primeiro colonialismo. Ela vê Calibã lutando, em vão, contra a imposta mundanidade de seu mundo, do qual ele agora se encontra alienado e no qual o discurso dominante o torna monstruoso. O estudo da autora tinha aplicação contemporânea. Quando ensinava na Nigéria durante os anos 1990, Federici 
testemunhou a remodelação violenta da economia nigeriana pelo Fundo Monetário Internacional. Esta, efetivamente, combinava tanto as transformações econômicas drásticas e as reconfigurações ideológicas das formas "naturais" versus as formas monstruosas da subjetividade que ela havia descoberto em suas análises do que ocorrera na Europa ao longo do século XVII.

Tanto a advertência quanto ao fato de que não é completamente reconhecida a adoção feminista do modelo warburguiano para se estudar a violência, a história e a imagem, quanto o exemplo de estudos feministas desafiando os modelos da modernização progressiva, e que expõem uma violência subjacente e fundada de modo específico no gênero, servem para introduzir um eixo a minhas reflexões sobre "para onde vai a história da arte". Não estou advogando o mergulho numa esquecida estrada secundária feminista, no mapa histórico da disciplina História da Arte. Em vez disso, a confluência de uma negligenciada experiência acadêmica feminista sobre Warburg no campo da História da Arte, ligada, por exemplo, à comunidade feminista alemã dos anos 1970, com suas conexões às recentes intervenções feministas materialistas de Federici, apropriadas por diversas historiadoras da arte, mais jovens e de destaque nos Estados Unidos propõe a questão: como 
tal violência contra as mulheres e seu significado tornaram-se invisíveis e deixaram de ser pensados? Como tal reconexão, tanto com a História da Arte warburguiana de Schade (muito antes da atual tentativa de propor como nova uma guinada a uma História da Arte em imagens, ou Bildwissenschaft) quanto com a análise cultural de Federici, poderia abrir perspectivas para as necessidades do campo hoje?

O pensamento excêntrico de Warburg como membro autoexilado mas, ainda assim, autoconsciente, da minoritária comunidade judaica numa Alemanha recém-unificada, no momento em que esse tipo específico de estatuto autocrítico de um pária (que Hannah Arendt mais tarde associaria a Marcel Proust e a Walter Benjamin) apontava para um lugar novo, em que o pertencer e o não pertencer, simultaneamente, tornavam-se possíveis, não deve ser associado a uma indústria da História da Arte agora em expansão, e que reivindica Warburg como o objeto novo de uma pesquisa idealizada, ou como a reencontrada figura do fundador de um novo horizonte: a cultura da imagem (POLLOCK, 2013a). O trabalho de Warburg oferece um arquivo digno de pesquisa contínua da história da disciplina e de suas rotas alternativas. Eu gostaria, todavia, de introduzir a contribuição primeira do autor não como um arquivo, mas, diferentemente, foca- 
lizando seu estudo psicologicamente cônscio da imagem, enquanto máquina de pensar visando o confronto com a História da Arte contemporânea ${ }^{6}$. É importante entender que Warburg não chegou ao método da iconografia em oposição ao método formal de Heinrich Wölfflin. As políticas de ambos os pensadores da história da arte eram infinitamente mais complexas do que essa caricatura de antagonismo que herdamos (LEVY, 2012). Para Warburg, a imagem era uma forma complexa, não um conteúdo isolado. Era uma figuração da memória, daquilo que uma vez havia sido protagonizado, originalmente, em gestos do corpo e que seria, então, formalizado e iconicamente rememorado - tais gestos e, a partir deles, seus afetos, sendo transmissíveis por meio da iconização [iconization] e se tornando disponíveis para circular através das culturas. A imagem é, a um só tempo, um traduzir temporal e espacial numa forma da memória carregada fisicamente, na qual a figuração desempenha papéis múltiplos. Ao enraizar as origens da arte na performance ritual e na imitação, e ao se mostrar sensível à transformação simbólica de afetos imaginados e ligados à fantasia, Warburg entendeu a arte como uma mediação - ele nomeou as realizações da arte como Zwischenraum $^{7}$ - entre aquilo que poderíamos, hoje, chamar de o Real das intensidades físicas e psicológicas em face da fragilidade humana na 
luta pela vida na natureza e na sociedade, e o Simbólico ${ }^{8}$. Warburg entende o simbólico como o espaço modelado culturalmente, cujo rememorar icônico poderia, de modo histérico, reviver e liberar afetos destrutivos. Ele poderia, entretanto, transformá-los em resoluções que moderariam tais intensidades afetivas em pensamentos. O pensamento é valioso, mas não quando posto como abstração. Warburg, dessa maneira, define os elementos específicos da imagem ou de tipos de imagem cuja história ele delineia numa Pathosformel, uma formulação do pathos, da paixão, do sofrimento, ou, em nossos termos, da intensidade afetiva, que rompe os limites da linguagem e habita o corpo como seu lugar e como seu alfabeto expressivo. $\mathrm{O}$ termo "fórmula", providencialmente, inclui a ideia de forma, a nos lembrar que o pathos é uma operação formal, não um conteúdo que possa ser separado de sua formulação. "Fórmula" invoca, igualmente, aquilo que pode ser repetido. Desse modo, o Pathosformel funciona esteticamente, subcognitivamente, talvez como uma formulação de intensidades que registra gamas específicas dos afetos humanos, do violento e extático ao depressivo e estático. O Pathosformel armazena intensidades como estas, mas também garante passagem potencial a um simbólico sublimador.

Resistindo tanto ao romantismo banal (a arte me comove?) 
quanto à formalização impessoal (a arte como um telos determinado pela norma), adotei diferentes estratagemas para me mover para além desse dilema. Durante os anos 1970 e 1980, a semiótica foi um daqueles estratagemas que franquearam as oposições forma/ conteúdo, ideia/afeto. De início, a semiótica fora o produto da intersecção de um primeiro modernismo linguístico do século XX (a questão modernista de Ferdinand de Saussure sendo "O que é a linguagem?”) com sua reconfiguração retardatária na antropologia “estrutural” (a questão modernista de Claude Lévi-Strauss sendo “O que é cultura?"). Todavia, ao retornar ao linguístico como parte da revolta dos estudos literários contra seu próprio romantismo, e ao reivindicar para si a ideia do formalismo russo, da literariedade [literariness] do texto literário, a semiótica chegou até nós, aos círculos da história da arte, de maneira não raro mais direta através da análise fílmica que adaptava a semiótica literária aos textos voltados ao filme.

Julia Kristeva, uma das teóricas da semiótica literária, foi, entretanto, crucialmente importante para o pensamento feminista, sob certos aspectos que ressoam o que venho discernindo do balanço warburguiano do Real e do Simbólico, mediado por aquilo que o historiador designou como imagem. Resistindo a vertentes na semiótica 
inclinadas a uma espécie de formalismo autoritário (as leis do significado), Kristeva nos alertaria para um fascismo potencial, inerente a todo formalismo, especialmente quando o sistema era entendido apenas como regras que não previam a possibilidade da resistência e de meios para a mudança. A autora voltou-se à psicanálise para reintroduzir o "sujeito da fala" no sistema de produção de sentido identificado pelas abordagens semióticas da linguagem, um sujeito concebido psicanaliticamente, cindido. Todavia, a formação desse sujeito jamais é completa. Ele está, portanto, perpetuamente "sob julgamento". Seu outro interno, seu concorrente perpétuo é um inconsciente. Ele carrega, igualmente, os vestígios impactantes da psicocorporalidade do estado da infância, ainda recalcitrante em face do significante e da lei mediante a qual o sujeito deve ser necessariamente constituído a fim de falar e ser sexuado. Kristeva argumenta que em razão do fato de tanto as pulsões quanto o pré-consciente existirem para além da lei, eles se oferecem como um meio para a mudança do sentido e para uma subjetividade cambiante, em seu "processo" sem fim (no francês, a palavra procès evoca tanto um litígio jurídico como um processo propriamente dito). As teorizações psicanalíticas da subjetividade e suas interfaces com a linguagem e com a instância do psicocorpóreo produziram a noção do "semiótico" específica de Kristeva. 
O uso que a autora faz do termo "semiótico" refere-se a um só tempo às predisposições daquilo que mais tarde tornar-se-ia linguagem - o ritmo, a assonância, a ecolalia - e à borda externa do reino da própria linguagem, uma zona liminar cujas fronteiras porosas mantêm-se em contato com os rastros de um semiótico pré-linguístico, corpóreo, emergente, através do qual a linguagem pode, constantemente, ser renovada e às vezes revolucionada. Tal conceito duplo de um semiótico que não apenas precede o simbólico, mas que também dança em suas fronteiras, permite a Kristeva identificar a arte, a música, a dança e a poesia como momentos do tocar e do mover - extralinguísticos, semióticos - o reino do sentido, ativando os traços inconscientes e mesmo precoces da fase semiótica formativa do devir-subjetividade. Se, por um lado, podemos encontrar elementos “semióticos" na arte em seus gestos, ritmo, superfícies e afetos (como na apropriação que Rosalind Krauss (1994) faz do inconsciente óptico de Walter Benjamin, para assinalar o informe na arte moderna), por outro, o que faríamos de sua imagem (que tanto pode ser abstrata como figurativa9)?

A imagem não é nem descrição nem iconografia. Melhor seria entendê-la como configuração. A arte abstrata, por exemplo, mesmo quando se mantém nos limites da figuralidade, produz um efeito que o observador experimenta como imagem - não de algo especí- 
fico, mas de algo com um tipo de estrutura através da qual ela pode ser lembrada. Defino esse tipo de imagem como a sustentação recíproca de acontecimentos visuais (não se trata apenas de um caos de materiais) e também como a sustentação, perante o observador, de um arranjo por meio do qual experimentamos, simultaneamente, um solavanco na direção da semiótica pré-linguística (ritmo, pulso e assim por diante) e a sensação, quase sempre frágil ou elusiva, de um tornar-se simbólico (formar, sustentar, dizer). Dessa maneira, Kristeva supera a oposição da forma (vazia) versus conteúdo (a representação explícita), não dissociando a imagem dos processos semióticos e da dialética do semiótico e do simbólico.

Em meu projeto duradouro de criar "intervenções feministas em Histórias da Arte", venho trabalhando a partir da dialética das subjetividades e da inscrição destas no campo da visão e da imagem. Procedendo assim, tenho buscado equilibrar a teoria de Kristeva com questões históricas de minha própria disciplina, cujo foco incide sobre resultados materialmente produzidos, mas capazes de afetar e "falar", e que nós equivocadamente chamamos de imagens visuais. Elas são tão tangíveis quanto visíveis, manufaturadas fisicamente, ao mesmo tempo que aptas a gerarem afetos e pensamentos, sendo que qualquer campo de visão é mediado 
pela tangibilidade e materialidade. Nesta empreitada, eu me dei conta de que minha interpretação da modelagem minoritária/ pária de Warburg, de uma história da arte como uma psicologia histórica da imagem, mostrava-se inesperadamente propícia ao estágio atual de meu projeto.

No curso de mais de 40 anos, engajei-me num projeto de reflexão de longo termo, que não procede mediante formas típicas da História da Arte, relativas a artistas, períodos, movimentos ou mesmo temas. Em vez disso, percebo agora claramente, tive de criar conceitos que possibilitaram minha reflexão voltada às problemáticas de gênero, classe, sexualidade, representação e diferença. Alguns desses conceitos são de natureza linguística e abordam a linguagem mediante a qual pensamos sobre a arte do passado, tal como o de "velhas senhoras" [old mistresses], expressão cunhada por Ann Gabhart e Elizabeth Broun para sua exposição feminista fundadora na Walters Art Gallery em $1972^{10}$, que apontava para as ideologias de gênero já encriptadas sob nossos termos, exclusivos de gênero, para falar de artistas. Outros conceitos concernem a problemáticas tais como "visão e diferença", ao passo que outros, ainda, propõem formulações: "referência, deferência e diferença", como impulsores estratégicos e dinâmicos das vanguardas (POLLOCK, 
[1988] 2003; Idem, 1993). Alguns propõem eixos para uma compreensão não essencialista, pós-colonial, da singularidade e do pertencimento histórico e geopolítico de cada artista: gerações e geografias. Muitos apresentam metodologias para a prática: diferenciar o cânone usando o desejo feminista ${ }^{11}$. O conceito com que atualmente trabalho é "o museu feminista virtual", primeiramente apresentado em 2007, e tendo uma segunda apresentação importante em 2013 (POLLOCK, 2007; Idem, 2013b).

O qualificativo virtual relaciona-se a "feminismo", não a “museu”. A virtualidade do feminismo, não cibernética, é filosófica. Conforme Henri Bergson nos ensinou, o virtual é uma potencialidade não exaurida e, no entanto, ainda não realizada, que pode ser atualizada de modos variados em diferentes tempos e lugares sem exaurir aquilo que ainda está por vir: virtualidade. Longe de estar superado, morto, acabado, o feminismo, quero propor, deveria ser entendido como um devir, neste sentido. De fato, estou sugerindo que toda radicalidade consistirá, não meramente no devir-mulher, tal como na formulação da cultura pós-falocêntrica, de Gilles Deleuze e Félix Guattari - mas no devir-feminista, conforme um sentido de longa duração do feminismo, como trabalho contínuo em prol da democracia, da justiça social e da 
coexistência segura e digna de uma humanidade plural e diversa. Aspectos da imensa virtualidade do feminismo-ainda-por-vir têm sido atualizados desde o período medieval, no Ocidente, e em culturas ao redor do mundo, em conformidade com suas escalas temporais e histórias específicas. No Ocidente, por exemplo, cada momento feminista foi moldado pelas diferentes prioridades e possibilidades da era de atualização, fossem estas as dos protestos contra uma misoginia brutal (Christine de Pizan) ${ }^{12}$; a da luta pela virtude (Mary Wollstonecraft) ${ }^{13}$; a do direito à cidadania política (movimento sufragista); a dos direitos ao trabalho livre e à dignidade humana, como também a uma identidade de gênero (o movimento antiescravista); a do direito à revolta (movimento das suffragettes) ${ }^{14}$; a dos direitos ao trabalho e à educação (início do século XX); a dos direitos ao próprio corpo, às próprias sexualidades e a da proteção em face da violência e da degradação (fim do século $\mathrm{XX)}$. Protestos feministas ao redor do mundo confrontam as intersecções de diferentes patriarcados e histórias, em suas variadas temporalidades, cada vez mais em diálogo recíproco à medida que a modernização abre novos caminhos para a mudança, ao mesmo tempo que implica novos riscos.

A igualdade (sempre incompleta e relativa a estados existen- 
tes de desigualdades seletivas) é uma pré-condição menor, ainda que necessária, para o feminismo; não é a destinação do feminismo. Os movimentos feministas mais recentes pelo mundo, ao longo das décadas finais do século XX, são apenas outros tantos episódios (e não uma segunda onda que obliteraria tudo o que a tivesse precedido, fazendo, dessa maneira, com que essa experiência anterior fosse, mesquinhamente, nomeada como uma primeira onda) que, entretanto, apresentavam uma dimensão nova, específica: uma dimensão cultural duradoura, em expansão, que além disso assinalava o primeiro engajamento profundo do feminismo com as artes visuais. Tal conjunção, mais ainda, transformava a arte à luz dos questionamentos e da criatividade surgidos do feminismo, que por sua vez era modificado pela novidade de sua guinada cultural, intelectual e estética. Outras atualizações da virtualidade do feminismo estão por vir. Elas serão, por seu turno, diferentes - a depender da configuração presente, tanto de possibilidades quanto de resistências. $\mathrm{O}$ mundo que artistas feministas, pensadoras e historiadoras da arte confrontam hoje é radicalmente diverso daquele dos anos 1970. Ele se tornou mais vasto e se vê marcado por eventos radicalmente diversos, como o fim do comunismo na Europa e o encetamento de novas fases da 
globalização desde 1989, o surgimento do terror e o 11 de setembro, a Primavera Árabe e seus desdobramentos preocupantes e ainda incertos, os conflitos que perseveram no Iraque e no Afeganistão e seus respectivos legados, a crise econômica mundial, economias emergentes. Mudança não significa necessariamente melhoramento, embora haja elementos inegáveis de progresso genuíno, em esferas limitadas e privilegiadas.

O modelo warburguiano de encontros concomitantes entre traços icônicos e materiais das várias lutas dos momentos culturais, de suas renovações ou regressões, reveladas pelo ressurgimento das tensões estruturantes das vulnerabilidades da humanidade vis-à-vis o mundo de que ela depende para a vida e para os outros com os quais o habita, possibilita um tipo de pensamento feminista sobre formulações a respeito do tempo-espaço e sobre as formulações-páthos [pathos-formulations] daí decorrentes. Essas formulações concernem à diferença sexual e, por isso mesmo, ao fazer-se da vida e à sua continuidade humanizada, à alteridade e a formações de subjetividades e sexualidades diferenciadas. Se a contribuição de Warburg aos estudos sobre a primeira Renascença deixava patente o quão extravagante era o fato de que a antiguidade pagã tivesse "retornado" para animar a cultura cristã e encetar sua longa jorna- 
da de modernização por meio do empréstimo de uma energética Pathosformeln do mundo pagão, o museu feminista virtual nota que a era moderna é marcada pela revolução e pela catástrofe. Tal museu convocou não a reabilitação das fórmulas clássicas da antiguidade no ocidente, mas o abandono delas, em face do horror do que se passou no real. A visão de um mundo habitável (paisagem) e do corpo humano como o locus idealizado de uma projetada humanidade (o nu, talvez) criado pelos gregos e aperfeiçoado por Rafael e companhia na arte italiana do século XVI, que então se tornava o modelo de uma educação acadêmica em arte, estilhaçou-se irremediavelmente em face do que se deu em terras europeias e em outros lugares, e aos corpos humanos, em atrocidades perpetradas pelos Estados totalitários e pelos regimes genocidas de meados do século $\mathrm{XX}$. Entre artistas pensantes e sérios, podemos detectar um senso da necessidade de invenção de novas formulações para o sofrimento e a intensidade afetiva adequados aos eventos sem precedente que moldaram aterradoramente o nosso mundo. Permitam-me repor essa afirmação: poder-se-ia dizer que o imaginário clássico, revivido de diversas maneiras pelo Ocidente, tão amiúde e sob viés político, foi violentamente estilhaçado à luz do que se passou com o corpo humano no Ocidente e, no tempo presente, por toda parte nos 
genocídios racializados como o Holocausto ou o de Ruanda, como também nos experimentos totalitários de caráter concentracionário $^{16}$ ao longo de todo o século $\mathrm{XX}^{17}$. O que possivelmente traz implicações para o modo como pensamos e escrevemos histórias da arte desde 1945.

Warburg propôs um conceito diferente de tempo - não direcional, não dado ao desenvolvimento, não historicista, mas curvo, recorrente, repetitivo e, sobretudo, traumático. O historiador acreditava que a nascente disciplina História da Arte fracassava, pois traçava histórias da arte sem retornos ou sem aquilo que reemerge e recarrega, isto é, sem Nachleben: este termo alemão difícil foi traduzido como "sobrevivência” ou "persistência”. Prefiro "pós-vida" [afterlife], que captura a vitalidade dos viventes e a relação com o pensamento freudiano, ao Nachträglichkeit, um conceito que Jean Laplanche traduz por "a posteriori” [afterwardness] ${ }^{18}$. Eu diria que a História da Arte fracassa porque, confrontada à história do século XX, ela continua a delinear uma história da arte sem ruptura e catástrofe.

Outrora era suficiente lamentar, ecoando a apreciação crítica que Meyer Schapiro fez da exposição "Cubismo e Arte abstrata", de Alfred Barr (Museu de Arte Moderna de Nova York, 1936), que 
o curador havia criado uma "estória da arte" [story of art], tomando cronologia por história, sobrevoando o incessante fluir da arte por cima de uma grade formal, de um tempo abstraído e, portanto, vazio (SCHAPIRO, 2010) ${ }^{19}$. Tendo escrito tal crítica em 1937, Schapiro não havia ainda absorvido as implicações que a Primeira Grande Guerra, a Revolução Russa de 1917, o craque da Bolsa de 1929 haviam tido na reconfiguração dos projetos da arte. Obviamente, ele ainda não era testemunha do que ocorreria na Segunda Guerra; especificamente, do experimento massivo de genocídio em escala industrial de duas comunidades da Europa - a dos judeus e a dos ciganos. Tendo em conta o fato de Theodor Adorno ter renomeado a era pós-1945 de "Nach Auschwitz" (nach significando tanto "depois” como "na direção de”), considero necessário doravante orientar os estudos em História da Arte na direção disso em relação a que viemos depois, e que Adorno e outros definiram como a nova e assustadora condição da vida e da morte neste planeta. Os choques se multiplicam, desde o viver sob a ameaça da destruição nuclear do pós-guerra, num mundo sustentado com os nervos à flor da pele, em Guerra Fria permanente, aos realinhamentos políticos pós-1989, ao evento aniquilador do 11 de setembro, às guerras prolongadas em diversos fronts na primeira década do século XXI, aos conflitos duradouros e irresolvidos, a um novo 
craque em 2007... e assim por diante. Se a arte mudou radicalmente suas formas e suas bases, será que deveríamos estar disputando a criação de uma nova categoria temporal chamada "contemporâneo", e discutindo metodologias apropriadas em História da Arte? Não se trataria ainda de outra tentativa à la Alfred Barr de conter nos limites de um modelo reconfortante e reconhecível as relações dramáticas e às vezes mesmo perigosas entre o histórico, nossos imaginários e os muitos e variados lugares, incluindo a arte, de um pensamento crítico ou de uma resposta às urgências do viver e morrer humanos em nosso tempo?

Warburg reprovava as vertentes da História da Artede seu tempo, às quais considerava "História da Arte esteticizante", irresponsáveis e enganosas. Se consentimos à História da arte que permaneça isolada no interior de seu próprio nicho, absorvida por uma história abstrata da arte, ela simplesmente deixa de ser uma disciplina histórica. Ela nem lê o passado historicamente nem lê o histórico na arte do presente para o qual está posta. Oferece uma falsa tela (um acobertamento) da história, apresentando uma história autônoma - uma história da arte isolada, na qual condições determinantes são demarcadas e domadas como pano de fundo ou vagamente reconhecidas como contexto. Para Warburg era necessário, para 
se pensar sobre arte, não a "História da Arte", mas tudo aquilo que à sua época a disciplina buscava contingenciar. A biblioteca multifacetada e interdisciplinar do historiador insta a uma deambulação intelectual, no sentido material e simbólico do termo, entre campos de conhecimento e de representação que se mostrassem necessários para que esta operação mnemônica, afetiva e simbólica profundamente complexa que ele chamava de imagem fizesse algum sentido. É importante notar que Warburg não dissocia inteiramente a imagem do sujeito que a criou. Ele não é autor de uma história sem artistas, mas tampouco se trata de uma história de artistas.

Uma História da Arte institucionalizada principiou como disciplina universitária nas universidades europeias de língua alemã, de onde foi exportada para o resto do mundo, durante o fim do século XIX e o início do XX (com a curiosa exceção da Grã-Bretanha, que apenas tardiamente passou a integrar esse universo, ao longo do século XX $)^{20}$. Desde a sua criação, sabe-se que as ideologias geopolíticas do nacionalismo moldaram a maneira como o campo ia sendo definido, mesmo que um eixo transnacional do "europeu" fosse construído por meio de uma apropriação seletiva de lugares no mundo antigo, como fundadores e infalíveis precursores do Ocidente. Tal como mostrou Robert Nelson (1997), rastreando classificações em teses de doutora- 
do na academia nos Estados Unidos, continuamos a trabalhar a partir dos enquadramentos básicos das culturas nacionais, em cujo domínio recaem as subseções relativas a períodos, escolas, movimentos, mestres e obras. Na condição de um erudito profundamente atento ao lugar perigoso assinalado ao outsider ou às minorias sob a homogeneizadora ideologia nacionalista, Warburg contestou o historicismo e o nacionalismo, rastreando a migração promíscua de imagens ao longo de uma planetaridade (termo que explicarei adiante) espaciomporal, muito tempo antes que conceitos como estes se tornassem rte do vocabulário crítico contemporâneo.

\section{VISADA OBLÍOUA: UMA LEITURA ${ }^{21}$ EM PROL DO PLANETÁRIO}

Em Death of a Discipline [Morte de uma disciplina] ${ }^{22}$, a crítica literária feminista pós-colonial Gayatri Chakravorty Spivak examina a crise, na universidade norte-americana, tanto dos "Estudos de Área"23 quanto da Literatura Comparada (SPIVAK, $2003)^{24}$. Os Estudos de Área haviam ampliado o alcance geográfico da pesquisa interdisciplinar relativa a diversos países e regiões de interesse dos Estados Unidos na era do Pós-Guerra/Guerra Fria. A Literatura Comparada servira para levar as línguas eu- 
ropeias à imaginação literária dos estudantes norte-americanos, evento menos obviamente motivado pela urgência política, mas, ainda assim, inestimavelmente político, ao encorajar as relações mundiais no contexto do pós-guerra. Não obstante, emergiram dessas fundações não necessariamente humanistas, mas antes política e ideologicamente motivadas, os espaços críticos nos quais floresceram estudos literários inovadores, forjados por iniciativas teóricas feministas, queer e pós-coloniais.

E hoje? - perguntava Spivak em 200o, antes, ainda, do 11 de setembro como nova baliza histórica -, num momento em que os impulsos que haviam gerado o espaço de possibilidade no interior dos Estudos de Área/Literatura Comparada já não têm relevância? Estarão tais projetos comprometidos por suas condições políticas de emergência, ou devem ser preservados em razão de seus efeitos críticos hoje valorizados, e ser reconfigurados a fim de se adequarem a novas exigências?

A exploração complexa empreendida por Spivak, das vicissitudes de seus campos justapostos, conclui com dois pontos relevantes à indagação sobre os dilemas em curso em nossa área disciplinar. Tal área parece estar se consolidando em torno de seus procedimentos tradicionais. Detecto certa reconsolidação de antigas 
vias ou, antes, signos de um profundo bloqueio das inovações recentes, que resultam de uma inflexibilidade, capaz de enfraquecer toda crítica mediante a indiferença prolongada, como também do fracasso real em aceitar que os argumentos dessa crítica devem ser digeridos e incorporados. Ao mesmo tempo, a área se vê, paradoxalmente, numa busca constante por novidades. Esse rumo, conforme quero sugerir, serve, igualmente, para manter em posição marginal as inovações efetivamente críticas de fins do século $\mathrm{XX}$ em nosso horizonte ampliado, ao sinalizar que tais inovações mostram-se hoje obsoletas, e isso, mesmo antes que elas tenham sido plenamente confrontadas. Dessa maneira, quem ainda precisaria conhecer as difíceis e desafiadoras Histórias da Arte, se elas estão ultrapassadas? Para onde vai a História da Arte?

Uma das novidades do momento é a "arte mundial" [World Art] ou os "Estudos de arte mundial" [World Art Studies] e outra, não propriamente uma novidade, mas uma sanha desenfreada, é a guinada generalizada nas áreas de pós-graduação, curadoria e de escrita sobre arte na direção do "contemporâneo" e dos estudos/práticas curatoriais. O que é a História da Arte se ela se vê transformada na companheira de um síncrono interminável e proliferante? Como vai o passado da arte se tornando um mero ar- 
quivo de referentes contra o qual o constantemente novo e emergente ver-se-ia legitimado? Que espécie de arte e de consciência histórica a modernidade líquida dessa "nova" nova história da arte promete, ou talvez esvazie? De que serão sintomas a globalização e o contemporâneo? Será que o telos hegeliano das tendências historicistas e desenvolvimentistas teria, de fato, se completado, todavia não como Hegel previra, na arte culminando na filosofia, mas na arte sucumbindo às curadorias encaminhadas pelo mercado, com seus textos acadêmicos a lhes legitimarem o valor, ambos os eventos tendo mais que nunca a economia por motor subjacente e refletindo a influência crescente de escritórios de arte e colecionadores?

Qual a razão de tal virada generalizada para o contemporâneo? O que a provoca? O que a mantém? Poderíamos entendêla como sintoma de uma mudança histórica mais ampla para a modernidade líquida, e como uma reorientação local da História da Arte para o seu próprio inconsciente econômico? O que acontece à História da Arte quando efetivamente abandona qualquer espécie de enquadramento histórico ou trabalho crítico da memória? Que relação existe entre a História da Arte "histórica" e a História da Arte contemporânea? 
Spivak argumentou que hoje confrontamos a globalização, e com isso ela designava o domínio sem peias, sem fronteiras do capitalismo transnacional, sujeitando-se assim a poucos controles e contrapesos locais, tal como fora possível no âmbito da fase nacional precedente desse sistema econômico político. No entanto, não queremos recuar da expansão geocultural de nossa imaginação e dos futuros que os projetos feministas internacionais pós-coloniais nutriram, porquanto ambos criaram coletividades transversas e diferenciadas. Spivak propõe, assim, um contraconceito virtual ao global, conceito que ela nomeia de planetário.

Proponho que o planeta substitua o globo. A globalização é a imposição de um mesmo sistema por toda parte. No trabalho em grade do capital eletrônico, nós chegamos a essa esfera abstrata esquadrinhada em latitudes e longitudes, recortada por linhas virtuais, outrora o equador e os trópicos etc. e, recentemente, submetida às exigências dos Sistemas de Informação Geográfica... O globo é nosso computador. Ninguém vive ali. Ele nos permite pensar que podemos ambicionar controlá-lo. (SPIVAK, 2003, p. 72)

E Spivak então propõe o planeta como contrafigura que se abre a um modo diferente de ser e pensar: 
O planeta é uma espécie de alteridade que pertence a outro sistema: no entanto, nós o habitamos, nós o tomamos em locação. Ele não é, de fato, passível de se ser posto em contraste seco com o globo. Não posso dizer: "O planeta, por outro lado...”. Quando invoco o planeta, penso no esforço requerido para figurar a (im)possibilidade dessa intuição que não pode ser derivada de nada. (SPIVAK, 2003, p. 72)

Nem dado, nem imaginado, o planetário, tal como o feminismo virtual, é um vir a ser baseado no trabalho que empreendemos, a um só tempo, em oposição ao domínio da globalização e em demonstração de fidelidade aos sonhos e desejos incompletos de uma justiça social profunda e real e do espraiamento da dignidade humana.

Finalmente, emergindo daquilo que Spivak define como nossa condição de humanos que acenam uns na direção de outros, apresenta-se o pensar do planeta [planet thinking]. Em vez de imaginar o mundo global como um espaço dominado pelo pensar do mercado, que torna instrumentos de uso as pessoas e a terra, Spivak define uma humanidade voltada a seus outros voltada a si mesma, de fato. É possível que o acenar em direção ao outro surja de noções tais como o amor materno (vínculos de família), o pertencimento a uma nação (identificação nacional) 
ou a uma religião (sermos os filhos deste ou outro ser divino, da terra ou da natureza como fontes do vínculo). Mas estas se provaram tão divisivas quanto antes haviam servido à criação de vínculos, localmente e de modo excludente. Spivak propõe o planeta como um conceito que substitui todos aqueles sem recair, como eles, no globalismo ou no universalismo, conceitos vazios, não raro secretando, sob sua fachada, seus próprios grupos de privilégio. Para Spivak, o tornar-se planetário envolve um tipo específico de trabalho que fazemos juntos. No caso da educação, como um locus singular e precioso, do encontro do outro por meio da literatura ou da arte, Spivak privilegia a leitura como uma necessidade fundamental. Tratar-se-ia de algo simples?

De modo crucial, ao substituir as fontes imaginadas de nossos vínculos com os outros, ou de nosso interesse por eles, o pensamento planetário interrompe, em seu curso, o tipo de centrismo (androcentrismo, eurocentrismo, cristianocentrismo e assim por diante) que críticos pós-coloniais repetidamente detectaram naquilo que permanece como gestos coloniais de expansão praticados por primeiro e segundo-mundistas. A alteridade, a dimensão do Outro que buscamos de modo a conhecermos melhor a nós mesmos, não deriva dos que permanecem centrados em situa- 
ções de privilégio. O pensamento planetário destitui muitos dos modelos de se pensar o mundo e seus Outros. Esta frase estranha significa que nem estamos pensando sobre eles nem os conceitualizando: "eles" tornando-se um outro para o "nós" que deles faz um objeto do pensamento. Nós pensamos uma questão ${ }^{25}$. Pensar é um processo, pensar a dimensão do Outro, pensar o mundo, pensar a diferença sexual significa confrontar o desafio posto por algo que já nos inclui, e do qual não podemos abstrair a nós mesmos como aqueles que "pensam sobre...”. Enquanto conceito que não podemos dominar inteiramente, o pensamento planetário é, portanto, uma transgressão de nossos modelos conceituais típicos, e do domínio que esses modelos codificam. O pensamento planetário envolve interpretar [reading] palavras, vozes, imagens, inscrições desses outros sujeitos planetários, com abertura e autofragilização [self-fragilization] - um conceito que aprendi de Bracha Ettinger ${ }^{26}$, e que pode nos tornar aptos a sentir tal configuração discriminadora de nossas relações com nossos outros a partir da mediação de práticas estéticas que valorizamos (ETTINGER, 2009). Tendo enumerado os nomes da alteridade - nomes para as figurações transcendentais daquilo que pensamos como origem desse dom que nos faz intentar na direção do outro: mãe, nação, deus, natureza - Spivak escreve: 
O pensar do planeta disponibiliza o envolvimento com uma inesgotável taxonomia de nomes como estes... Se imaginarmos nós mesmos como sujeitos em vez de agentes globais, criaturas planetárias em vez de entidades globais, a alteridade persiste como algo que não deriva de nós; ela não é nossa negação dialética, ela nos contém, na mesma medida que nos arremessa para longe. E é assim que pensá-la é já uma transgressão, pois, não obstante nossas incursões na direção daquilo que metaforizamos de um modo diferente, como o espaço externo e o interno, o que está acima e para além de nosso alcance não é contínuo conosco nem, aliás, especificamente descontínuo. Devemos, de modo perseverante, nos educarmos a nós mesmos nessa atitude mental. (SPIVAK, 2003, pp. 72-73)

O pensamento planetário é uma atitude mental em cuja direção nós mesmos devemos nos orientar, por meio de uma prática que ela denomina de "leitura" [reading]. A leitura diz respeito à figuralidade da linguagem, que se torna o espaço para a poiesis, para um fazer ou vir-a-ser do sentido, o qual advém através de nosso trabalho, com suas figurações, suas poéticas, movimentos e lutas por articulação. Emprestamos da literatura o termo "leitura", de modo que agora lemos filmes, lemos imagens. Eu traduzo os aspectos retóricos e, por conseguinte, figurais da linguagem literária tanto na análise semiótico-visual quanto na análise francamente formal de todos os aspectos 
daquilo que Ettinger formula como o elaborar da arte [artworking] (usando uma economia freudiana do "trabalho" como labor e transformação, mais do que como produto finalizado: o trabalho de arte) ${ }^{27}$.

Não posso pretender alcançar, de imediato, todas as implicações do argumento de Spivak, rico como ele é em associações profundas com sistemas filosóficos e literários tão mais amplos do que o meu, não raro apenas euro-norte-americano; um mundo imaginativo, oferecido ora através da História da Arte, ora de suas limitadas histórias da arte. Eu o cito aqui porque o esforço para se compreender como tal pensadora está trabalhando incansavelmente questões que nos concernem a todos nas artes e humanidades é precisamente o que sempre julguei necessário a mim mesma, na condução de meus próprios estudos voltados à produção de diferenciadas histórias da arte. A História da Arte de nosso tempo acabou por sofrer de seu próprio isolamento intelectual, ao definir sua especificidade contra outros modos de pensar - em vez de em efetiva conversa com eles.

Talvez fizéssemos melhor evocando as condições intelectuais muito mais generosas sob as quais se formavam os iniciadores da História da Arte como especialidade acadêmica, antes que ela existisse enquanto tema completamente independente. Os auto- 
res em língua alemã, que seguimos respeitando como fundadores da História da Arte, como Warburg e Wölfflin, estudaram teologia, filosofia, filologia, começavam a descobrir a antropologia e a primeira psicologia, e não receavam em lançar mão de empréstimos às várias formas das ciências emergentes. Tal envergadura intelectual não corresponde ao diploma em nossas artes liberais ${ }^{28}$ do século $\mathrm{XX}$, porquanto o nível profundo em que esses eruditos haviam estudado tais fontes de pensamento claramente ultrapassavam o repasto superficial pinçado por meros degustadores no supermercado da deambulação intelectual da graduação.

O segundo ponto que quero destacar em relação a Spivak é que ela apreende as implicações de seu próprio campo - os estudos literários - infletindo-se em algo tão vasto como a vida humana neste planeta. Não se trata de humanismo convencional. Trata-se de algo consoante às condições alteradas - o planetário em processo de constituição versus a globalização - do pensamento humanista, alterado tanto histórica quanto teoricamente. Ao sugerir o planetário como uma contraforça à arrogância do mapeamento cartográfico e, por consequência, da leitura "em translação" das culturas do mundo, ou aos gestos conciliadores do multiculturalismo em face dos novos públicos-alvo de estudantes, a refletirem os efeitos da glo- 
balização, Spivak invoca Sigmund Freud para perguntar "Será que isto tornará estranha [uncanny] nossa morada" (FREUD, 1919)? A morada em questão é o mundo, tal como ele se terá constituído à luz de nosso trabalho de analistas culturais. A referência de Spivaka Freud nos faz lembrar que a palavra alemã para estranho é unheimlich ${ }^{29}$, a qual desfaz a noção do familiar: o heimlich. No ensaio “O estranho", sua formulação mais enigmática sobre as fontes do afeto estético, Freud argumentou que os efeitos aterrorizantes - estranhos - de se deparar, inesperadamente, com algo "familiar" - capaz de afetar - sinalizam o retorno de um traço reprimido da primeira morada, o corpo da mãe ou, antes, o canal do nascimento. Spivak salta do celestial preâmbulo linguístico de Freud e, então, das associações abertamente corporais do autor, para argumentar que o propósito do trabalho planetário não é nos fazer sentir em casa, mas desarranjar todo domínio do mundo, e fazer-nos frágeis em face do afeto e da alteridade.

Em nossa tentativa de perseguir a "planetaridade" [planetarity] como algo capaz de fazer nossa morada unheimlich ou estranha, construiremos uma alegoria da leitura [reading], através da qual o sistema discursivo mudase da vagina ao planeta como significante do estranho, exemplificando o colonialismo nacionalista e a pós-colonialidade. Isto se daria em consonância com meu método: o gênero como um instrumento crítico geral, em vez de algo a ser levado em conta em casos especiais. (SPIVAK, 2003) 
Se outrora o pensamento do corpo como morada primordial gerava a ansiedade que acompanha todo retorno do recalcado, será que o confronto com o planeta enquanto condição da vida $h u-$ mana, do qual nos extraviamos e ao qual deveríamos agora retornar, não terá também gerado uma certa estranheza, uma inquietação que é, no final das contas, um dos afetos-chave do estético? Será, do mesmo modo, tal a razão pela qual valorizamos o estético não como aquilo que devemos mapear, explicar, conhecer e dominar, mas como algo através do qual deveríamos aprender outra maneira de viver neste planeta, com a alteridade de outros tempos, e também com a alteridade que, no presente, outros são para nós?

Spivak também pensa com o gênero, como eixo a um só tempo real e efetivo de relações de poder diferenciais e assimétricas, e como uma organização simbólica de pensamento, imagens e fantasias hierárquicos. O que ocorreria, portanto, se levássemos a sério o pensamento feminista, em vez de imaginar o "gênero" como esta "coisa" que pessoas "generificadas" [gendered] - isto é, mulheres - desconfortavelmente insistem em repisar, e que poderia ser reconhecido não mais do que como um aceno ao politicamente correto? Nós capturaríamos o poder figurativo do gênero como um re- 
curso do pensamento, que ultrapassa a alçada particular daquele, tornando-o um instrumento crítico a desfazer a hierarquia e indo ao encontro da alteridade. Em outras palavras: se em vez de pensar ansiosamente sobre alteridade como morada primeira ou origem - corpo materno, mãe, nação, terra e todas as figuras que nos abrigam no princípio - por consequência, levando-nos a que nos arrisquemos a fundamentalismos - nós considerássemos o planeta - o tencionar de uns na direção de outros dos coabitantes de um mundo compartilhado, mas apenas "tomado em locação" - como a alteridade constitutiva de nosso trabalho como pensadores e intelectuais ou criadores, se procedêssemos assim, quais seriam os efeitos em nossas práticas como intelectuais e professores trabalhando nesse campo radical da arte enquanto fazer, representar, transformar? Quais seriam as estratégias a que recorreríamos a fim de praticar tal pensamento planetário na escrita e em sala de aula? Como o estudo das Histórias da Arte poderia facilitar o pensamento planetário e resistir às implicações homogeneizadoras da globalização enquanto falso apagamento de um pensamento nacionalista e hierárquico, profundamente incrustado nas convenções da História da Arte e em seu maquinário?

Permitam-me retornar à História da Arte, que se pode definir 
como um sistema geopolítico de pensamento. Fundada no século XIX, numa era que testemunhou a formação dos nacionalismos, a disciplina serviu para sacralizar o modelo que discrimina a arte em culturas nacionais, ao mesmo tempo que providenciou fantasias de fontes distintas em cultura, linguagem, religião e formas de arte, em prol das narrativas culturais das origens das nações. O nacional se reflete na configuração de nossos museus, nas categorias de nossos livros e no formato de nossos currículos, nos quais a arte do mundo se vê dividida, nas eras pré-nacionais, em regiões, e em escolas nacionais nas eras modernas. Terá sido um dos efeitos desse modo de pensar o privar de um espaço de legitimidade nas Histórias da Arte grupos transversais tais como o de mulheres ou de minorias culturais ou sexuais?

A História da Arte disciplinar reverencia uma imaginação politicamente cartográfica. O gesto duplo, de imaginar uma História da Arte mundial e mover-se na direção do contemporâneo globalizado, falha em desconstruir tal legado. Como começar a pensar em termos "planetários" - em vez de globais - os primeiros sendo enraizados, conectivos, diferenciadores e os últimos, abstratos, homogeneizadores e indiferentes? Uma vez mais, os legados do pensamento feminista seguem perscrutando. Teresa de 
Lauretis identifica um sistema falocêntrico no qual se produz não a diferença sexual, ainda que nele pareça se produzir o masculino e o feminino como par complementar, mas a promulgação de uma “indiferença sexual”, na qual existe, com efeito, apenas um sexo, o masculino e o seu outro, o espaço vazio do não masculino, que se denomina feminino. A diferença sexual falocêntrica não imagina a alteridade; ela reprime a possibilidade desta, ao estabelecer a hegemonia de um sexo (espelhada e sustentada por seu não outro esvaziado) (DE LAURETIS, [1988] 2007).

Como podemos coabitar o planeta se consentimos que seja estranho, isto é, uma fonte de ansiedade que pode ser importante porquanto resiste ao domínio de nossa própria sensação de fragilidade ao criar modelos abstratos? A recomendação de Spivak, ou antes, a explanação que oferece daquilo que nos resta como professores na área de humanidades, diz respeito a uma prática da leitura e do ensino da leitura. No lugar da visão de satélite, de um globo que de longe traveja o espaço com as telecomunicações, precisamos estar próximos, aqui embaixo, aos loci das inscrições estéticas e das tentativas de dar voz às experiências vividas nos espaços das pessoas comuns do planetário. Ao demonstrar o que isto significa em seu próprio campo por meio da leitura rente [close reading] 
de textos de diferentes espaços geoculturais e de suas literaturas, cada um em seu idioma próprio, todavia lido, necessariamente, em tradução (não a tradução como uma substituição), Spivak esclarece que algo tem de acontecer nesse encontro que ela chama de leitura e que não é nem busca da identidade (do escritor/artista) nem identificação (com o escritor/artista). "O que estou tentando fazer é forçar uma leitura. Gostaria de saber se o texto poderia, talvez, sustentar uma guinada, de monumentos identitários a documentos voltados a uma reconstelação" (SPIVAK, 2003, p. 91). Eis o eco da constelação benjaminiana. Quão frequente é o propósito da História da Arte de situar um trabalho, estabelecer-lhe a identidade em relação a um autor, um lugar, um movimento, um estilo, uma cronologia, uma cultura, um espírito nacional? Ligando isto às lições de Kristeva, para quem a literatura é um trabalho de distanciamento e transgressão da autoridade e das fronteiras, conforme se discutiu há pouco, a ideia da leitura oferece um espaço de reconstelação de relações da comunidade planetária a uma imagem ou a um texto - não a interpretação de um objeto reificado da cultura.

Ao mesmo tempo que sintonizado com modos de pensar que não corroboram os procedimentos característicos do expansionismo cartográfico dominante na disciplina, o gesto de engajamento 
de Spivak, de repudiar a dominação, é o exercício da leitura rente [close reading]. Enganosamente simples, a leitura pressupõe, no entanto, uma diferença no texto e uma produtividade a ele, uma resistência ao domínio, que podem ser demonstrados, ativos, pelo tipo de prática de leitura que busca, "persistente e repetidamente, solapar e desfazer a tendência definitiva do dominante, de apropriar-se do emergente. Ela não pode deixar-se a si mesma constituir-se apenas pelas demandas do multiculturalismo liberal" (SPIVAK, 2003, p. 101). O processo de leitura de textos em suas figuras de diferença requer treinamento na sala de aula, um estar junto com o professor no tempo e no espaço. Será possível aprender a ler dessa maneira por meio de cursos on-line em escala de massa [Mass Open On-Line Courses]? Não creio. Spivak insiste que o ensinar e, portanto, o aprender, é íntimo, com o texto e com a comunidade momentânea de leitura entre pares e gerações.

Sempre achei que muito do que se oferece em aulas de História da Arte é um tipo de disciplinamento do pensar sobre arte. A disciplina requer dos estudantes que aprendam os costumes característicos, não apenas dos procedimentos próprios da disciplina para o estudo da arte, mas também de seu modo de narrar uma estória da arte. O disciplinamento é tão mais urgente quanto maior sejam 
os públicos da História da Arte ou a potencial influência deles. A consistência e mesmo a uniformidade da mensagem asseguram a transmissão de capital cultural para a geração seguinte ou através de grupos sociais. Os museus desempenham uma função similar, mas pela via da arquitetura e da curadoria, contando a seus públicos incansavelmente a mesma estória, por meio da seleção, do layout e dos painéis de texto. A mesma estória é a estória politicamente apropriada [right] (não a politicamente correta [correct]!). Uns poucos toques novos podem realçar a velha estória, tais como métodos de aula que mencionam perspectivas feministas, queer ou pós-coloniais, mas apenas como suplementos potenciais, que então são incluídos tão somente para serem posicionados à margem.

O que estou explorando não tem a ver com a rejeição de um quadro de procedimentos disciplinadores em prol de outro, a conduzir a novas disciplinas, tal como a ruptura com a História da Arte na direção da cultura visual, esta última rejeitando os focos da arte, do artista e da sucessão histórica como objetos de estudo. Se, tanto do ponto de vista semiótico quanto histórico, o fazer da arte e as negociações complexas de suas práticas seguem como o foco visado, como as aulas de História da Arte poderiam ser imaginadas enquanto locus onde se aprende a ler? Aquilo que está sendo lido 
(não se trata, necessariamente, de algo que seja feito a partir de uma base verbal, uma vez que estamos falando, aqui, de ler uma pintura ou um trabalho de arte) deixa de ser, dessa maneira, um objeto, para inserir-se nas taxonomias existentes do conhecimento em História da Arte (períodos, movimentos, estilos, iconografias, a obra, intenções pessoais, desenvolvimento artístico, gêneros e assim por diante); torna-se aquilo de que poderíamos vir a tomar conhecimento, de modo parcial, e diferentemente, como o próprio mensageiro da alteridade, abrindo-se à virtualidade do planetário. Que espécie de conhecimento seria produzido, e que espécie de sujeitos nos tornaríamos por meio dessas leituras que fazem da arte não o suporte das narrativas que aprendemos a habitar, ou em que fomos disciplinados a habitar, mas o espaço crítico de seu frentamento-desenvolvimento, como parte desse entender o

anetário enquanto uma ficção que estamos continuamente em processo de forjar e que buscamos compartilhar?

\section{A IDOLATRIA RESISTE AO ICONOCLASMO}

Em 1978, Rozsika Parker e eu concluímos nossa primeira colaboração, no livro finalmente publicado em 1981, com o título 
Old Mistresses: Women, Art and Ideology [Velhas Senhoras: mulheres, arte e ideologia] (PARKER; POLLOCK, [1981] 2013). Ao rever a já notavelmente considerável literatura internacional sobre “mulheres artistas", dirigíamos a nós mesmas uma questão específica: por que nosso projeto terá sido desdenhado como ridículo por nosso supervisor, acadêmico conceituado e mais tarde diretor de um grande museu de arte moderna? Se ao menos pudéssemos entender o que fazia com que estudar mulheres na História da Arte parecesse a ele trivial e risível, sentimos que teríamos sido capazes de expor não apenas preconceitos obsoletos, indiferença ou oblívio em relação a mulheres artistas, mas também o caráter estrutural de certo androcentrismo e sexismo ativos - hoje diríamos performativos - e institucionalizados. O que descobrimos é que a disciplina História da arte sistematicamente produz o efeito (desejado) de um cânone androcêntrico e exclusivista. O cânone seletivo é assegurado por meio de termos já enviesados pelo gênero que declinam - "arte/artista" - , cuja aparente e impérvia neutralidade disfarça a apropriação e alocação desses termos por uma masculinidade privilegiada do ponto de vista geopolítico, social e étnico. A análise feminista das formações, hábitos e protocolos da disciplina, como também de seu próprio inconsciente 
político, desnudou o manto de invisibilidade, de maneira a proporcionar reformulações críticas dos modos como os diversos públicos fazem história da arte e leem os trabalhos de arte e seus locais institucionais, críticos e expositivos de prática e distribuição. Mesmo quando uso este vocabulário, sua exterioridade aos termos convencionais da História da Arte identifica os modos de uma resistência hegemônica a tal escancaramento crítico, resistência encrustada em seus termos preferidos que são, com efeito, seus modos de pensar.

Em 1980, mostrei como uma abordagem feminista poderia frutificar numa análise da construção mítica de "Van Gogh". Identifiquei a produção discursiva de um sujeito artístico para o trabalho de arte, tal como a história da arte protagoniza, em suas diversas formas, notavelmente no período moderno (POLLOCK, 1980). A arte é, claramente, algo que é feito; mas “artista”, claramente, não é sinônimo de produtor. "O artista” torna-se o locus mítico das fantasias que o investem, de autoria, individualidade, intencionalidade e de uma interioridade autônoma na qual os sentidos se fazem. Esse artista-como-signo é, conforme sugeri, um efeito de procedimentos de escrita e convenções discursivas que asseguram o trabalho de arte como o produto e, por con- 
seguinte, como o lugar de inscrição de um sujeito autônomo e autocriado de tipo particular: o sujeito artístico que é "apartado" e sacralizado pelos modos da construção discursiva.

Complementei esta análise inicial com um estudo bem mais extenso de questões relacionadas à autoria porque se tornara necessário resistir à banalização da ideia barthesiana da morte do autor, e desse modo expliquei o texto dele mais detidamente e comparei a função do autor em textos literários, nos quais ele na verdade servia, segundo Barthes, para instalar a autoridade do crítico/intérprete, àquela operação algo diferente, mas paralela, do artista na prática da História da Arte, especialmente na crítica modernista (POLLOCK, [1989] 1996). Também confrontei o exasperado problema da relação entre vida e trabalho de arte, a narrativa biográfica do artista e os procedimentos formais do trabalho de arte. Estes polos gêmeos - de Giorgio Vasari e Roger Fry - digamos assim, permanecem irresolvidos e preocupantemente incompreendidos entre especialistas e estudantes, mesmo hoje. Vincent Van Gogh foi, uma vez mais, meu estudo de caso. Em primeiro lugar, explorei modelos não autorais que permitiam, não obstante, considerar o artista tanto como produtor intencionado quanto agente criativo participando do trabalho que ele ou ela fa- 
zia - mesmo sem nunca o determinar inteiramente -, trabalho que por sua vez estaria, uma vez realizado, sujeito à leitura textual. A leitura textual, na teoria literária, significa intertextualidade, na qual o sentido se produz em relação a códigos, gêneros e referências. O ponto-chave é que o processo de assim ler um trabalho não envolve rastrear, retroativamente, a fonte de seu sentido até chegar ao artista, paradoxalmente alcançado, no trabalho, pela crítica convencional, e então projetado para além dele, como sua fonte, anterior e personificada. Barthes sugeriu que, enquanto na crítica convencional o "autor/artista” é efeito da análise textual do trabalho, o crítico inventa o artista como um espaço imaginado, que sustenta e personaliza a totalidade dos níveis e sentidos do texto, de modo a melhor firmar sua própria interpretação de crítico, que a disfarça como se fosse intenção mesma do artista. Tal ficção de um autor, como Barthes revelou, oculta uma leitura mais crítica do artista como apenas um nível de significado num texto plurívoco, com inúmeras relações laterais a outros textos e lugares e à história. Torna-se possível, então, introduzir considerações sobre os efeitos específicos do artista como um produtor que tem gênero, pertence a uma classe social e é social e culturalmente posicionado, em vez de fonte individualista e penhor de um sentido humanista que flutua 
livre de determinações sociais (palavra que se refere, aqui, tanto às pressões quanto aos limites no interior dos quais o produtor inevitavelmente opera, social, cultural e esteticamente).

Em 1999, revisitei a problemática emergente da História da Arte como discurso, que Parker e eu havíamos explorado em Old Mistresses [Velhas Senhoras] ${ }^{30}$. Depois de quase 30 anos de crítica feminista da exclusão de gênero, a questão já não era "O que é o cânone e como é formado?" ou mesmo "Por que ele é seletivo?" Doravante, minhas questões eram: “O que mantém o cânone na ordem do dia?"; "O que assegura sua persistência em face da tremenda evidência de um trabalho e de histórias criativos, realizados internacionalmente por mulheres tanto quanto por homens?" Desta vez, minha resposta levou-me de Barthes e Michel Foucault à psicanálise, a máquina de pensar que lida com as forças não racionais que modulam ações, fantasias e sistemas de pensamento. Argumentei que a tenacidade do cânone não poderia ser a resposta para uma ignorância acadêmica modulada pelo gênero e potencialmente corrigível. Em vez disso, tal tenacidade acusava um investimento psicológico profundo no artista, tanto quanto fantasias narcísicas a respeito dele. $O$ cânone - assim segue meu argumento - é parte do aparato que produz e preserva a ficção do 
indivíduo criativo, então identificado por mim como o efeito discursivo profundo de procedimentos normativos da História da Arte representados pelas formas típicas de pesquisa e escrita: a monografia e o catalogue raisonné. A psicanálise me permitiu entender tanto a ligação passional ao artista como núcleo do projeto da História da Arte moderna quanto a persistente inabilidade para ampliar o campo de preciosas subjetividades criativas que poderiam ser reconhecidas como artistas ${ }^{31}$. Um tipo diferente de resistência teria de ser desconstruído.

Como testemunha da produção das primeiras monografias que haviam moldado Leonardo e Michelangelo, entre outros, sob as formas então novas de uma História da Arte acadêmica, firmada na expertise [connoisserial], Freud identificou um nó afetivo na opção pela forma da monografia. O nó consistia na fascinação irresistível pela biografia do artista. Nós, os experts [connoisseurs] e também o público, estamos mais interessados, de acordo com Freud, nas estórias da arte como estórias de artistas porque o "artista" funciona, na literatura, como uma figura que contém tanto a primeva idealização infantil do pai onipotente quanto a criação substitutiva e a projeção narcísica de um herói que assoma quando a falibilidade do pai é exposta. Essa 
combinação do teológico (a idealização do pai) com o narcísico (a idealização do herói) sobredetermina o investimento na construção do artista como o sujeito da arte porque o artista é tanto um espelho ideal para o amante das artes (a dimensão narcísica) como uma figura mantida à distância, figura outra, e elevada pelo gênio a uma diferença suficiente para reignizar a veneração teológica (a dimensão idealizadora) ${ }^{32}$.

Seguindo a lógica de Freud, fica evidente porque nunca ocorreu a integração da diversidade à História da Arte. A mulher-enquanto-artista jamais protagoniza tal integração, em relação a qualquer sujeito que seja - aí incluídas as historiadoras da arte. Em relação ao sujeito masculino, heterossexual ou queer, a mulher não é o lugar nem da idealização teológica nem da narcísica. Se aceitarmos por ora o conceito de Freud, difícil embora astucioso, do sujeito feminino como sujeito formado mediante o recuo desiludido à negação do feminino-materno, como também mediante a inveja do fálico, a ensejar uma espécie de identificação transgênero com o falo e a aspiração de recebê-lo indiretamente do pai, poderemos ver que não há, igualmente, nada de valor naquilo que é codificado como feminino (narcísico)/materno no imaginário falocêntrico no qual ela - do mesmo modo que ele - 
é formada. Em muitos casos, as mulheres especialistas comodamente se identificam com a idealização dual do homem-artista canônico, por meio da extraordinária flexibilidade psicológica da feminidade, gerada pela força da inveja, um tanto vilipendiada, mas de fato criativa.

Tal reflexão, dessa maneira, ainda suscita a questão mais profunda relativa a como terá sido possível emergir algum interesse feminista por artistas mulheres - estou tomando tal questão pelo viés psíquico. Em Differencing the Canon [Discriminando o cânone] (POLLOCK, 1999), discuti o capital cultural e psíquico mínimo que resulta do trabalho a respeito de mulheres artistas, tão desvalorizado ou destituído de valor ele é no âmbito da estrutura psíquica falocêntrica que sustenta as bases fantasmáticas do cânone. Propunha, portanto, o neologismo "desejo feminista" para introduzir, politicamente, como também psiquicamente, um contra desejo pela diferença, que hoje eu nomearia, usando um conceito de diferença sexual estética criado por Bracha L. Ettinger (2006), de fascinância [fascinance] pelo outro-mulher. O desejo feminista não é erótico no sentido homoerótico. Liga-se à fascinância, que Ettinger define como um anelo, por parte da garota-que-ainda-não-é-mulher, de aprender o que é tornar-se mulher 
adulta através de um momento prolongado do olhar [gazing] - que por sua vez não é especular, mas antes uma abertura ao aprender através da observação e da absorção. Esse anelo deve encontrar reciprocidade na hospitalidade que a outra, a mulher já madura, volta à garota cheia de curiosidade, de um jeito que, sem ser erótico, ainda assim não está isento de sexualidade enquanto parte inevitável da transmissão que sustenta a garota em seu tornar-se-mulher. A outra mulher oferece o tempo e o espaço para que essa garota-sob-a-mulher (tal é o termo que Ettinger emprega para designar a feminidade adulta, imanente e iminente, do sujeito feminino) aprenda a feminidade não como o outro denegado produzido pelo falocêntrico complexo de Édipo, mas como aquilo que Ettinger designa pelo termo ffam - femme-fatale-outra-mãe [femme-fatale-autre-mère] -, que se pronuncia do mesmo modo que a palavra francesa femme, mulher. As proposições de Ettinger estão em consonância com os insights fragmentários que se manifestaram ao próprio Freud, em sua produção final, sobre a potencialidade para as formações da subjetividade e da sexualidade feminina, as quais não eram explicáveis por seu modelo edipiano (FREUD, [1933] 1973, p. 153). Subsequentemente, a teorização do feminino tendeu a se ver ligada apenas à fase 
pré-edípica e aos conflitos do eixo mãe/filha. Ettinger introduz o conceito de um encontro formativo do sujeito feminino com a desejabilidade feminina, localizada num lugar de feminidade diverso do materno, permitindo que imaginemos o modo como poderíamos, culturalmente, por meio dessas disposições psíquicas, investir valor e desejabilidade, por exemplo, nas criações artísticas e intelectuais de mulheres; desse modo, a autora explica o fundamento para um nexo psíquico diferenciador, paralelo à idealização do pai/herói masculino que, conforme sugeri, sustentou a adesão a um cânone quase totalmente masculino.

Enquanto a lógica fálica da formação do sujeito prossiga reinando como soberana única sobre o nosso entendimento da subjetividade - a despeito do tanto que pesquisemos, que escrevamos sobre o assunto, e que defendamos a qualidade estimulante de artistas que são mulheres -, uma base sólida persistirá nos sujeitos masculinos e também nos femininos, falicamente identificados, que talvez sejam incapazes de reconhecerem tal fascinance ou a ela se abrir, permanecendo indiferentes em face do desejo feminista. Aquilo que poderíamos conscientemente esperar - que as evidências transformem o mundo dos especialistas, de tal modo que este aceite uma visão inclusiva das histó- 
rias da arte - está inconscientemente bloqueado.

A teórica de cinema Kaja Silverman oferece outra leitura das disposições psíquicas necessárias para nutrir a consciência feminista, com seu trabalho sobre a reavaliação, levada a cabo por Julia Kristeva, das facetas materno-homossexuais, e sobre a proposição apresentada por Freud, da coexistência dos complexos positivo e negativo (no sentido fotográfico) de Édipo. Freud admitiu um complexo de Édipo negativo, em que a mãe é desejada pela filha. Isso facilita o suporte representacional para outra cena na qual aquela que é a outra mulher - a m/Outra e a Mãe [the m/Other and the Mother] - adquire desejabilidade por aquilo que fizeram, pensaram e elaboraram (SILVERMAN, 1988). Em formulações diferentes, tanto Silverman quanto Ettinger nos lembram de que, para mudar a economia psíquica de nossas disciplinas, temos de querer conhecer de modo diferente: isto é, modelos falocêntricos do desejo e das formações psicológicas podem inibir o desejo de conhecimento daquilo que foi por eles apresentado como indesejável enquanto figura de identificação e idealização. O feminismo pode ser entendido como uma reescrita do desejo, lastreado na fascinância.

Quando, além disso, tal como Spivak sugere, usamos o gê- 
nero como uma máquina de pensar, somos também capazes de ver que o gênero, como um orquestrador simbólico da diferença e da valoração assimétricas, coloniza todos os modos de relação de diferença - de classe, étnica, colonial, geopolítica e assim por diante - permitindo que um único, apenas, figure o ícone de identificação da desejabilidade narcisística e de veneração teológica. Em razão do fato de que os danos perpetrados pelas ordens dominantes de classe, raça, colonialismo, homofobia e, mais, pela autodefesa contra a incapacitadora hegemonia da masculinidade branca levam masculinidades outras, feridas, a investir na identificação fálica. Mesmo estas julgam difícil se acomodarem à ideia de se identificarem a outros artistas-sujeitos indesejáveis e não idealizáveis, como as mulheres.

O que adveio de toda essa incursão pela formação discursiva e pelos investimentos psíquicos que moldam as estruturas mais amplas ou profundas do pensamento da História da Arte? Eu responderia: muito pouco. Vejo muito pouco impacto efetivo desses escritos feministas na disciplina. Sem dúvida, há algum reconhecimento do projeto feminista - respeitável, na melhor das hipóteses, superficial na pior. É também evidente o respeito pessoal pelas especialistas que o promoveram, mas, não raro, 
sem um engajamento mais profundo com o desdobramento contínuo de cada projeto intelectual ou do projeto geral do próprio pensamento feminista. O feminismo é, mais frequentemente, confinado a um nome de autor, em vez de ser apreendido em seus diferentes universos de ideias, que solicitam ser confrontados, digeridos e até mesmo integrados a todo o campo de especialização. A reivindicação multilocalizada e internamente agonística da crítica feminista no que concerne às práticas hegemônicas da História da Arte de incorporar as interpretações analíticas dos nódulos neuróticos e do inconsciente político da disciplina foi ignorada ou - eu diria mesmo - reprimida. Ao esquadrinhar o campo na atualidade, não encontro evidências de que a disciplina se permita mudanças sob qualquer aspecto que tornasse normal tal leitura crítica de sua formação disciplinar. Rotulando-a de "feminista", e ao dar-lhe este nome, relegando-a às margens mesmo quando parece reconhecer-lhe a presença, o campo recusa a transformação feminista da prática da História da Arte, transformação a um ponto em que o gênero e a diferença sexual tornar-se-iam partes inalienáveis de nossas operações de pensamento, em vez de um caso especial, um acréscimo, algo de que aquelas "feministas" podem se ocupar. 
Traduzido em termos simples, a idolatria (do artista), profunda na História da Arte, resistiu ao iconoclasmo crítico da intervenção feminista e de outras intervenções, como também os reprimiu. Pior: recentemente passei a notar o quão pateticamente inadequado tem se revelado aquilo que é apresentado ou ensinado como uma intervenção "feminista" na arte ou na História da Arte. Ambas as Histórias da Arte, androcêntrica e feminista, estão criando para o feminismo o que não posso chamar senão de uma memória ruim. Não obstante as tentativas vigorosas de muitas teóricas feministas de esquerda e de direita para mudar a institucionalização acadêmica de uma narrativa indicativa e provisória, convertida à única narrativa do feminismo e da História da Arte - as histórias das ondas ou das duas gerações, das tendências norte-americanas versus as britânicas na História da Arte, as oposições de tipo culturalista/essencialista versus teórica/ pós-estruturalista/pós-modernista -, permanece a "verdade" que é dada, hoje, à maioria dos estudantes, os quais, por este motivo, não conseguem discernir uma história mais interessante e infinitamente mais complexa, que mantém muito pouca relação com esses tropos recorrentes de gerações, ondas e oposições teóricas.

Quando ouço comunicações apresentadas na Conferência 
Anual da College Art Association ou encontro estudantes prospectivos de pós-graduação de toda parte, e que querem estudar história e teoria da arte feministas, deparo-me com distorções profundas, apresentadas como verdades históricas inquestionáveis, de sorte que me vejo capaz apenas de uma vez mais voltar-me a minhas fontes psicanalíticas para explicar esse sintoma inconscientemente repetido. Nem, de fato, um impulso mortífero, reduzindo a categorias redutoras, opositivas, a complexidade, o brilho intelectual e a beleza ética de uma vasta paisagem mundial da criatividade feminista e do pensamento feminista em arte, é capaz, efetivamente, de matar um pensar com essa paisagem.

A socióloga britânica Claire Hemmings (2010) estudou as vertentes da escrita da história da teoria feminista nas ciências sociais, na obra intitulada Why Stories Matter: The Political Grammar of Feminist Theory [Por que estórias importam: a gramática politica da teoria feminista $]^{33}$. Hemmings discerniu três narrativas recorrentes influindo na presente historicização da experiência intelectual feminista - progresso, perda, retorno. Cada narrativa lidou com posições e trajetórias do campo desde os anos 1970 e de maneiras que refletiram diferenças nas políticas e nos investimentos em momentos que foram vistos como progressistas (do simples 
culturalismo a um pós-estruturalismo teoricamente sofisticado); obliteradores (do ativismo genuíno a um teoricismo arcano), ou um retorno calculado (mediante a integração de aspectos daquilo que as outras duas narrativas representam, seja como progresso ou perda). Na História da Arte, do mesmo modo, geralmente escrevemos histórias de vertentes recentes, sob o crivo de nossas distintas afiliações. A narrativa do progresso exalta as guinadas críticas voltadas à teorização da diferença e os estudos sociais, feministas, queer e pós-coloniais. A narrativa da perda desacredita tal interferência teoricista à luz de uma orientação ativista unificadora e com um foco na diligência das mulheres. Os reconciliadores tentariam misturá-las e combiná-las, remendando o antagonismo real da irrupção histórica da mudança.

Desde o final dos anos 1980, feministas vêm produzindo tais historicizações - algumas em resenhas de artigos, como nesta revista, por exemplo (PETERSON; MATHEWS, 1987); outras, em exposições (como "WACK! Art and the Feminist Revolution or Global Feminisms”, 2007) [“WACK! Arte e revolução feminista ou feminismos globais"] 34 . Essas cartografias não geográficas - isto é, a tentativa de dar sentido a um complexo campo de ações, muitas delas singulares e, ao mesmo tempo, de compartilhar uma inspi- 
ração comum no movimento das mulheres e num pensamento feminista em expansão - procuram impor grades de significado pela data, local, por categoria, por temática. Nenhum artista, contudo, faz arte com o intuito de corresponder a essas grades, de ser igual a quem quer que seja, mesmo que haja, lateralmente e historicamente, conversações implícitas que alimentam o fazer da arte. Algo se perde nesse gradeamento. Os fatores que possibilitam conversações duradouras entre singularidades criativas - artistas - são, de fato, encontráveis, mas de maneiras não determinadas, em condições sociais, materiais, econômicas, históricas e culturais melhor deslindadas na leitura rente [close-reading] e nos estudos de caso ${ }^{35}$. O que aconteceria, dessa maneira, se deixássemos de criar categorias como feminismo, arte feminista, ou mesmo uma História da Arte feminista, e considerássemos a problemática de que certas artistas ou historiadoras da arte julgam relevante trabalhar nessas e com essas questões, ou se tentássemos acompanhar debates sólidos e encorajadores, e então lêssemos trabalhos específicos (artísticos e analíticos) criados por conta daquilo que elas estivessem fazendo, e pelos efeitos que estes trabalhos estrategicamente tivessem produzido nos espaços e locais em que tivessem intervindo, em vez de tentar encaixá-los, interminavelmente, como se fossem ícones de um 
determinado artista ou grupo que, de modo redutor, ilustrassem a grade da História da Arte e a categorização?

Permitam-me dar-lhes um exemplo. Uma estudante que veio a mim porque começara a se interessar pelos "conflitos entre marxismo e feminismo no início dos anos 1970" entrevistou-me recentemente. Ela tinha em mente a querela T.J. Clark-Pollock ${ }^{36}$, o que equivale a dizer que o pensamento de diferentes historiadores da arte, suas conversações, questões compartilhadas e argumentos específicos mostrar-se-iam vertidos em ícones, nos nomes de dois autores situados em oposição um ao outro, à maneira agonística de um ranqueamento. Para começo de conversa, tais termos - marxismo e feminismo - não nos ajudam a alcançar o que se passava com a História da Arte na Inglaterra na década de 1970. O feminismo ainda não era um ismo. Eu era atuante no movimento das mulheres - é assim que entendíamos nosso momento, na passagem dos anos 1970 para os 1980. O movimento na Inglaterra tinha pouca utilidade para as artistas, e por certo nenhuma para historiadoras da arte. A arte a custo seria relevante a essa luta profundamente política, que reescrevia cada aspecto da vida cotidiana. Mas, como eu me via, então, no processo de me tornar uma historiadora da arte, a questão feminista 
do gênero na arte e na História da Arte se apresentava de imediato a mim em meu local de trabalho "cotidiano": na academia. A pergunta era óbvia: existiram/existem mulheres artistas? Mas o que significaria descobri-las e, então, indo além, deixar claro como e por que os traços delas haviam, tão recentemente, sido apagados e, ao mesmo tempo, também encontrar modos de escrever sobre elas sem transformá-las na cifra negativa "do artista”? O que se tornaria a História da Arte se ousássemos instá-la a pensar de maneira inclusiva?

Ao mesmo tempo, a insatisfação com uma abordagem formalista reducionista, que não era o formalismo entendido criticamente, levou-me à uma leitura arrebatada de certos livros que apareciam como tábuas de salvação enquanto eu lutava tentando encontrar um caminho para ser historiadora da arte. Um deles, escrito por T. J. Clark, retomava e redefinia uma prática em História da Arte já existente no período pré-guerra, a qual havia sido substituída por um despolitizado formalismo no pósguerra. $\mathrm{O}$ aspecto do livro de Clark que interessava era o fato de revigorar a pesquisa em História da Arte com debates intelectualmente ricos sobre as relações complexas entre o histórico e o formal. A história social da arte jamais fora antiforma, jamais puramente 
iconografia, jamais voltada ao conteúdo, ao invés de formalista. A história social da arte de Clark lançava-se a inquirir o modo como poderíamos entender as negociações modernistas entre experiência e forma, as mediações protagonizadas na arte entre história e ideologia mediante procedimentos, materiais e efeitos. Tais questões foram tão necessárias para forjar um pensamento histórico e histórico-materialista sobre relações de gênero e sobre a formulação dessas relações quanto foram para pensar a racialização e seus efeitos - quanto foram, para Clark, para pensar relações de classe e suas inscrições estéticas, seja no fazer da arte, seja nas reações a ela. Conforme se abriam inúmeras vertentes com propósitos comuns no cinema, na fotografia e na História da Arte, em projetos queer, pós-coloniais e feministas, como também sócio-históricos, havia um rico intercâmbio, do mesmo modo que discussões sérias. Não era uma questão de campos e identidades, mas de debates sustentados em conferências, revistas, conversas e atividades de ensino. Estávamos tentando - a cada livro, a cada artigo, a cada conferência, a cada grupo de discussão - enfrentar massivamente temas difíceis, com implicações consideráveis para a natureza de nossos estudos. Alianças e constelações se formavam e eram remodeladas, nutridas 
por muitas fontes, a ponto de cada uma delas gerar leituras escrupulosas e debates subsequentes. Aquilo que, em retrospecto, poderia ter sido inteiramente arrastado por narrativas de progresso ou de perda, era experimentado pelos participantes na forma de possibilidades novas e constantemente desafiadoras, a auspiciarem projetos de longa duração. Minha própria experiência nos grupos de discussão - os debates, as pequenas revistas que faziam com que estes circulassem, o encontro com artistas que não raro lideravam os grupos em tais debates e também no reconhecimento crítico das vertentes e apostas em jogo, seja na arte como no mundo - informou minha própria compreensão histórica da necessidade de uma leitura cuidadosa das condições sob as quais quaisquer práticas emergiam, e ainda minha resistência profunda à mentalidade-ismo, firmada como maneira de tornar claras tanto as práticas artísticas como as do pensamento. Armado com o -ismo, o estudante vê meramente o que confirma esta designação e negligencia o trabalho envolvido ou a problemática que está sendo confrontada, talvez de modo inepto. Em vez de um retorno integral ao projeto historiográfico de tentar entender os acontecimentos históricos sem saber o que aconteceria depois, temos de abandonar o hábito do gradeamento retros- 
pectivo, mesmo enquanto lancemos mão de cada instrumento que encontremos na sacola de métodos de pesquisa histórica e de nossas habilidades de leitura, para pensarmos sobre o que os trabalhos de arte e a arte realizam [do] em suas condições ampliadas.

Alguns defendem que esta argumentação deveria ser feita sempre no tempo presente. Concordo que a arte está sempre realizando [doing] - trabalhando - no presente. Tal é o paradoxo. Vermeer, por exemplo, é de quando? Os trabalhos, nós sabemos, foram fisicamente produzidos mediante uma prática situada, temporalmente precisa, na Delft de meados do século XVII. Contudo, se entendemos a arte no sentido de sua contínua performatividade, o trabalho, enquanto arte, acontece a cada vez que uma pintura de Vermeer é confrontada com um observador. O historicista procura atar "Vermeer" ao tempo-espaço da produção e à identidade do artista, que essa precisão histórica produz. Mas a pintura produz seu próprio tempo-espaço que, então, não se pode confinar, embora seja interessante, especificamente para os propósitos da História da Arte, indagar como os seus primeiros observadores viram cada trabalho, e sob quais condições tal prática havia se tornado possível. A capacidade de não ser confinado no tempo é, de fato, parte daquilo que faz da pintura pintura, tanto historicamente, como um evento na arte ocidental, quanto em sua 
capacidade de ocorrer de modo contínuo, em atos de ver apartados de muito longe do momento e do lugar de sua emergência.

Aqueles que usassem apenas o tempo presente introduziriam uma capacidade semiótica que é parte da presença do trabalho como uma condição de presente [presentness]. Ao mesmo tempo, aqueles de nós historicamente engajados sem serem historicistas também desejam explorar esta outra questão: o que tornou tal obra de arte possível no momento de sua emergência, e o que o fato de saber isso, mesmo agora, quando a confrontamos em seu contínuo trabalhar, nos diz sobre a alteridade daquele seu outro lugar gerador no tempo e no espaço? A história - estou sugerindo - não oferece nem anterioridade ao trabalho nem uma mera sucessão de acontecimentos do tipo causa-efeito. Defino-a seja como singularidade (seu próprio tempo-espaço), seja como uma alteridade enriquecedora (diferença daquela do especialista ou do observador). A configuração de fatores à luz da qual um católico convertido chamado Johannes Vermeer se lançou a pintar, dia após dia, pequeninas telas e painéis a óleo numa cidadezinha da recém-formada República mercantil holandesa, predominantemente protestante, ligada através do comércio e viagens a outros centros de produção artística e memória cultural e política configurados de modos totalmente diversos, de fato me interessa 
suficientemente para que eu procure encontrar meios de integrar o que está acontecendo em qualquer pintura, quando a observo, ao que terá feito com que tal acontecimento se tornasse possível no momento em que tal pintura foi realizada.

À estudante indagativa, inquirindo as tensões entre marxismo e feminismo nos anos 1970, eu reagia projetando a cena de comunidades informais, imbricadas umas nas outras, mas combativas, animadas pela necessidade compartilhada de mudar os paradigmas que havíamos recebido, sem trair as eficácias remanescentes, as condições de existência ou mesmo os potenciais ainda não ceifados de um campo - o da História da Arte - que nos apaixonava. Nunca havíamos imaginado que estivéssemos em conformidade com algum movimento futuro; estávamos engajadas em debates e no pensar sobre a arte e a história. De modo irônico, impor o conceito de movimento, precisamente, estanca o movimento, faz com que se percam de vista as atitudes, as viragens, os retornos, as perdas de foco, os fios reencontrados, as disputas, os resultados acumulados, as fidelidades de longa duração e assim por diante. Sou incapaz de reconhecer o que quer que seja das memórias de meu próprio tornar-me uma historiadora da arte, engajada nos grandes desafios da disciplina, nas grades 
redutoras, banais e sufocantes que hoje são transmitidas aos estudantes em apanhados e manuais, os quais, além disso, fazem murchar e homogeneízam projetos intelectuais muito distintos sob uma bandeira única - feminismo -, ou fazem do feminismo o lugar de oposições simplificadas e de antagonismos a outros -ismos igualmente empobrecidos. Talvez isso explique o uso que faço do neologismo "máquina de pensar" para designar fontes teóricas e historiográficas. Sinaliza minha resistência ao confinamento em categorias e meu desejo de ressaltar o trabalho sem fim do próprio pensar.

O impulso de tornar a História da Arte inteligível, enquanto tema, a estudantes prospectivos e a leitores interessados, assinala, a meu ver, uma terrível distorção. Vários -ismos são inventados; indivíduos tornam-se ícones de ideias, não produtores em transformação dos corpos de pensamentos em movimento. A diversidade e o debate são tabulados em oposições ou desenvolvimentos, como deslanche ou preterição. Sob a categoria de feminismo, projetos intelectuais radicalmente diversos, de tantas pensadoras e especialistas criativas, diferenciando-se agonisticamente sob o ponto de vista de classe, de etnicidade, de sexualidade e de higidez de cada corpo [able-bodiedness], atuando de 
modo consistente e desenvolvendo-se ao longo de um período de 40 a 60 anos, são congelados no tempo, reduzidos ou a "posições" em competição, ou a uma sucessão de gerações edípicas, que se podem sumarizar numas poucas linhas. O estudante ou $o$ leitor torna-se espectador em uma espécie de arena intelectual cruenta. A História da Arte nos declara a todos nós meramente contingências suas, alguns sendo considerados a espinha dorsal, outros, a atração secundária, a ser mencionada, de modo alusivo, quando se tipificam categorias e se arrolam nomes. Aquelas dentre nós identificadas com o campo dinâmico do "feminismo" não aparecerão, por esse motivo, como as intelectuais metodológicas gerais, ou nas seções destinadas ao pós-colonial, ao queer, à abordagem sócio-histórica, não obstante a urgência com a qual, de minha parte, vejo a mim mesma constantemente desafiada a engajar-me em todas essas grandes questões, seja no que quer que eu faça.

Por fim, creio que o modo como o feminismo é isolado e rebaixado enquanto participante igualitário e influente nas questões mais amplas sobre autoria, textualidade, sociabilidade, subjetividade, leitura, história, significado, prática e assim por diante, produz uma caricatura que efetivamente esvazia sua contribuição 
ao presente em movimento da disciplina. Sobretudo, ao se identificar feminismo com gênero, este quase sempre entendido como sinônimo de mulheres - uma categoria de gênero que de fato não implica tudo no que concerne internamente e transversalmente ao "generificar" [gendering] -, faz-se com que o pensamento e a rática feministas se tenham tornado tão malquistos, indesejas, desinteressantes e pouco estimulantes quanto são "mulheres", conforme sugeri, na estrutura geral dos hábitos psicologicamente androcêntricos e sexistas da disciplina em sua totalidade.

\section{MOMENTO DE ACERTO DE CONTAS}

Longe de estar em posição de propor novas direções, ou concordar que a História da Arte esteja atualmente perdida, ou rumando para qualquer lugar que seja, argumentei em prol de um momento de acerto de contas quanto ao lugar que ela veio ocupando, em sua história imensamente rica, nos últimos 50 anos. Por que - pergunto - a memória da História da Arte é tão seletiva, tão falha, tão autodestrutiva, tão seguidamente repressiva em relação a alguns de seus momentos mais radicais, mesmo entre os recentes? Que modos de pensar liquidam ou adulteram 
os elementos mais importantes de sua própria historiografia? Eu formulei isso psicanaliticamente, uma vez que tal é a histórica máquina de pensar modernista voltada ao estudo do desejo, do inconsciente e da fantasia. Também insisti na integração de práticas de leitura sócio-históricas e feministas, pós-coloniais e queer, contrariamente à sua categorização segregada, algumas dessas práticas ainda vivas, outras mortalmente enrijecidas.

Enquanto escrevo este apelo exaltado a uma leitura mais rente [closer reading] e à uma compreensão efetiva - senão a uma digestão e a uma transformação - de nosso passado intelectual recente na disciplina, com seus vigorosos debates críticos sobre a diferença, me dou conta de que talvez estejamos defrontados a dificuldades ainda mais desesperadoras, posto que as artes e humanidades são brutalmente marginalizadas por políticas que valorizam exclusivamente uma educação tecnológica, de modo raso definida como útil sob o prisma econômico (POLLOCK, 2012b). "Definhe, História da Arte!" [Wither Art History!] 37 seria um enunciado mais próximo daquilo que nossos governos estão efetivamente afirmando. A História da Arte, uma disciplina, na Inglaterra, já pequena e relativamente jovem, encontra-se profundamente ameaçada enquanto pauta universitária pelas políti- 
cas do atual governo, que estão reduzindo o número de estudantes, encerrando graduações e deixando sem trabalho estudantes brilhantes de pós-graduação. Também nós, talvez, logo sejamos história, mas uma história, conforme espero, que possa permanecer como fonte para o pensar. Quem dera a história das histórias da arte que a História da Arte nos permite conhecer torne-se genuinamente inclusiva e gravemente respeitosa: ao abraçar o desafio de um pensamento planetário e de sua urgente defesa humanista, de um ler para aprender a diferença em vez de sucumbir à massificação global orquestrada mediante uma categorização redutora. 
1. Para uma discussão marcadamente relevante da lógica da preterição na formação de um imaginário cristão, diante da supressão da coetaneidade do Judaísmo e sua recorrência na teoria moderna, incluindo a psicanálise, ver BIDDICK (2003).

2. De modo a contornar a falta de distinção equivalente na língua portuguesa, neste texto será empregado o termo composto "História da Arte", com os dois substantivos grafados com as capitais em caixa alta, para designar a disciplina ("Art History", conforme esclarece a autora), e o mesmo termo com os dois substantivos iniciados em caixa baixa - "história da arte" ("History of Art") - quando referir-se ao campo histórico da arte em geral. [N.T.]

3. Explorando a ambiguidade política do termo "pós-modernismo", Hal Foster identificou tendências contraditórias. Uma forma do pós-modernismo foi conservadora, antimoderna, tomando o pós-moderno, em certo sentido, como um escape do moderno, numa volta à tradição. A outra tendência foi um pós-modernismo crítico, percebendo-se a si mesmo como acerto de contas, seja com as contradições e os desenganos do moderno, seja como uma exploração crítica de sua empreitada incompleta (Cf. FOSTER, 1983).

4. Permitam-me esclarecer meus termos. A História da Arte se refere à instituição e à disciplina que estudam um campo, a história da arte. Minha intervenção feminista e pós-colonial desafia a hegemonia da História da Arte androcêntrica e eurocêntrica, e afirma uma pluralidade de histórias, Histórias da Arte ainda sendo escritas ou ainda se fazendo (Cf. POLLOCK, [1988] 2003).

5. Foi este um debate central nos anos 1970, que a economista feminista norte-americana Heidi Hartmann abordou no trabalho "The Unhappy Marriage of Marxism and Feminism: Towards a More Progressive Union" (HARTMANN, 1979).

6. 0 conceito de máquina de pensar nos afasta das histórias intelectuais das ideias ou daquelas dos grandes pensadores, e lida com a prática ou um corpo de trabalho enquanto conjunto complexo de meios para se pensar através de problemas específicos. 0 conceito é parcialmente tributário das intervenções filosóficas de Gilles Deleuze e Félix Guattari, que 
buscaram deslocar o pensamento do psicologismo e sugerir, em vez disso, uma série de “máquinas", tais como as máquinas desejantes, a máquina literária, às quais acrescento a máquina de pensar. A ênfase recai no arranjo no qual um lugar ou uma pessoa qualquer é um elemento, e que focaliza antes combinações e conexões do que entidades discretas.

7. 0 termo Zwischenraum designa em alemão, literalmente, intervalo, espaço ou vazio. [N. T.]

8. Eu principio os termos Real e Simbólico com letra maiúscula na tradição do vocabulário de Jacques Lacan. 0 Real é a zona do trauma, na qual um protossujeito é afetado sem que tenha os meios para processar os eventos intervenientes, e o Simbólico é a zona dos pensamentos e palavras. Warburg, por certo, não empregava tais conceitos, mas imagino que seu trabalho, ao empurrar os limites de uma exploração pré-psicanalítica da subjetividade e da história psicológica da imagem, encontre uma providencial elucidação nas formulações lacanianas de uma zona afetiva do não pensado [unthought affective zone], e de uma zona de afetos transformados em pensamento. 0 Simbólico principiado com letra capital marca a diferença de uma zona ou registro da significação e da subjetividade em relação à compreensão normal de algo que é simbólico em termos semióticos.

\section{Ela se reporta a BENJAMIN (1987).}

10. Ann Gabhart and Elizabeth Broun foram as curadoras dessa exposição reunindo obras de 35 artistas, da própria coleção permanente da instituição, e que teve por inspiração o célebre texto de Linda Nochlin, “Why have there been no great women artists?" [Por que não existiram grandes artistas mulheres?] (NOCHLIN, 1989). A mostra, intitulada "Old Mistresses: Women Artists of the Past" [Velhas senhoras: artistas mulheres do passado] ocorreu em 1971, e teve pouca repercussão, tendo sido registrada num breve ensaio na revista do próprio museu. Em 1976, uma grande mostra intitulada "Women Artists, 1550-1950" [Artistas mulheres, 1550-1950] quase obliterou a memória de "Old Mistresses...". Com curadoria de Linda Nochlin e Ann Sutherland Harris, foi inaugurada com grande repercussão de mídia, no Los Angeles County Museum of Art, apresentando 150 obras de 83 mulheres artistas, incluindo seis importantes trabalhos de Artemisia Gentileschi (apud BARKER, 2020). [N. T.]

11. Ainda que alguns leitores venham a reconhecer que esses "conceitos" coincidem com títulos de livros, é importante sublinhar que tais títulos marcam um campo conceitual, mais do 
que um tema, e é esperado que se transformem em conceitos com os quais trabalhar, para além do livro em que são introduzidos, na criação de um projeto feminista em constante frutificação.

12. Christine de Pizan ou, nos textos mais antigos, Christine de Pisan (1364-1430) é considerada a primeira "mulher de letras", em língua francesa, tendo vivido de sua escrita. Sua obra é prolífica, contemplando tratados de política, filosofia e escritos poéticos. No fim da vida, retira-se a um convento, onde escreveu poema dedicado a Joana D'Arc (Ditié de Jeanne d'Arc). [N.T.]

13. Mary Wollstonecraft(1759-1797) escritora, teve notável trajetória intelectual e política, ao advogar aguerridamente a igualdade social e educacional das mulheres. 0 núcleo central de suas ideias foi formulado na obra A Vindication of the Rights of Woman (1792) [Uma defesa do direito das mulheres], considerado uma referência histórica fundadora pelos movimentos feministas. [N.T.]

14. 0 movimento das suffragettes surgiu na Inglaterra, onde o voto feminino fora primeiramente defendido pela escritora Mary Wollstonecraft em seu livro A Vindication of the Rights of Woman (1792) [Uma defesa do direito das mulheres]. A reivindicação aos poucos tornou-se central no debate intelectual na Inglaterra, a partir da década de 1850, atraindo inclusive fileiras liberais, como o escritor John Stuart Mill, que junto à esposa Harriet encampou a defesa do voto das mulheres. Por volta de 1870 , já se contavam pelo país inúmeras agremiações conclamando o direito ao voto. Em 1897, diversas sociedades sufragistas convergiram para criar a União Nacional das Sociedade de Mulheres Sufragistas, e lideranças femininas surgiam, em face de resistências de governos e dos setores mais conservadores da sociedade britânica. Emmeline Pankhurst e sua filha Christabel emergem como lideranças influentes do movimento. Em 1906, em face do retorno ao poder de segmentos políticos refratários a mudanças, a campanha das sufragistas militantes recrudesce, lançando mão de ações contundentes e às vezes violentas, que não raro resultavam na prisão das militantes - era o movimento das suffragettes. 0 voto feminino na Inglaterra foi legalizado em 1918. [N.T.]

15. Uso "momento" em contraste consciente com a categorização disciplinar levada a cabo pela História da Arte, do tempo em períodos e da arte em movimentos. "Momentos" indica um conceito diverso de temporalidade, fundamente derivado do legado de Walter Benjamin, 
que por sua vez fora atraído pela espécie de pensamento cultural que havia se desenvolvido em torno de Warburg e sua biblioteca. Benjamin usou termos como "constelação" para pensar conjunções e relações. Seus pensamentos, ainda fragmentários, estão reunidos em um de seus últimos manuscritos, "Sobre o conceito de História" (1940), publicado na obra Sobre o conceito de história. Edição crítica (BENJAMIN, 2020).

16. Na obra que escreveu em coautoria, Pollock comenta o termo: “A palavra 'concentracionário' foi forjada por David Rousset, político francês deportado, que tendo regressado de Buchenwald, escreveu uma análise do sistema daquilo que chamou de 'o universo concentracionário'. Em 1951, a teórica da política Hannah Arendt publicou sua análise substancial do 'mal', no rescaldo do universo concentracionário. Em As origens do totalitarismo, Arendt (2012) mostrou como a busca pela dominação total tem suas raízes no imperialismo, no racismo e no desenvolvimento da nação, e é então realizado em sua forma mais rematada no nazismo alemão e na União Soviética de Stalin" (SILVERMAN; POLLOCK, 2015). [N. T.]

17. Para a distinção entre o Holocausto e o "concentracionário", ver SILVERMAN; POLLOCK (2015). Ver também POLLOCK (2013c).

18. 0 conceito freudiano, traduzido largamente como ação diferida [deferred action], refere-se ao intervalo de tempo entre um evento que ao ocorrer não pode ainda ser assimilado, e que, portanto, é traumático, e uma ocorrência ulterior dele, que pode herdar a sobrecarga do afeto não assimilado associado ao primeiro trauma. Tal evento, entretanto, vem à luz nesta segunda situação, criando 0 paradoxo de uma repetição originária. 0 pensamento freudiano, dessa maneira, curva o tempo de volta sobre si mesmo, enquanto mantendo, conceitualmente, os dois eventos apartados. Assim, não se trata meramente de uma sensação de persistência ou sobrevivência, mas de reanimação de um evento ou memória ainda carregado, por sua reconstelação, de um momento posterior, de sorte que ambos demandam e herdam esta primeira carga de afeto. Às vezes essa relação pode ser regressiva; outras vezes, é uma renovação. Para Warburg, como também para Freud, a questão analítica é, em certo sentido, sempre "política". Sobre Nachträglichkeit, ver LAPLANCHE (1999).

[N.T] Note-se que, segundo Laplanche e Pontalis, o substantivo Nachträlichkeit e o adjetivo 
(ou advérbio) nachträglich (que em francês aparece como après-coup) são termos usados por Freud com frequência, com relação à concepção que ele tem da temporalidade e causalidade psíquicas, uma vez que "há experiências, impressões, traços mnésicos que são ulteriormente remodelados em função de experiências novas, e do acesso a outro grau de desenvolvimento"; ver LAPLANCHE; PONTALIS (2016, p. 33).

19. A capa do catálogo da exposição "Cubism and Abstract Art" [Cubismo e arte abstrata], organizada por Alfred Barr, mostra uma representação diagramática das origens da arte moderna no trabalho de quatro mestres: Paul Cézanne, Paul Gauguin, Georges Seurat e Vincent van Gogh. Deles brotam setas que se agrupam em grandes movimentos tais como 0 Cubismo, conduzindo, finalmente, à abstração geométrica e não geométrica, por intermédio de vários movimentos menos célebres. 0 mapa cria um destino para a arte moderna. Tratase de uma brilhante conceitualização, ordenando o caos de círculos e grupos concorrentes segundo uma lógica que não é desprovida de perspicácia e relevância no que concerne a uma interpretação da trajetória da arte no início do século XX. Autores na vertente da história social da arte usaram repetidamente essa capa diagramática como espécie de atalho para apresentar aquilo a que eles se opunham. Com isso, rebaixava-se o êxito de Barr do ponto de vista historiográfico e, não raro, falhava-se em alcançar a significação mais profunda daquilo que era assim ocluído e, ainda mais importante, a razão pela qual elementos evidentes da complexidade da arte moderna e seus inúmeros participantes eram invisibilizados e tornados ininteligíveis no esquema do crítico. A contra-alternativa de Schapiro, e sua análise politicamente fina da abstração como o resultado de uma lógica que estava relacionada ao capitalismo contemporâneo, a suas alienações e oposições imaginativas, não se fizeram, por contraste, tão hegemônicas quanto aquilo que, no modelo de Barr, tornava inimagináveis as fundações sociais e políticas do modernismo.

20. Para uma extraordinária história das formações nacionais da disciplina na Europa, ver RAMPLEY (2012).

21. As formas do verbo read, como também o substantivo reading, aparecem inúmeras vezes ao longo do texto. Como é sabido, na língua inglesa, as formas verbais e o substantivo podem vir a designar, além de atividades ligadas à leitura de materiais textuais, também a atividade mais ampla de interpretar, analisar, ponderar, comentar - um objeto, uma situação, elementos não exclusivamente textuais. Dessa maneira, as declinações do verbo read e o 
substantivo reading não foram sempre traduzidas estritamente como ligadas a atividades de leitura do texto ou, mais amplamente, ao letramento; diferentemente, a tradução optou, a cada caso, pelo termo em português mais pertinente ao contexto em questão. Resta notar que o termo "close reading" foi central para os autores ligados ao New Criticism, corrente da crítica literária que se disseminou nos círculos acadêmicos dos Estados Unidos nos anos 1930-40, preconizando a primazia absoluta da análise "interna" das obras; no ambiente intelectual norte-americano do período, o método da "leitura rente das obras" assinalava uma reação marcante à atenção que as correntes historicistas davam a materiais biográficos e sociológicos. Neste artigo, a própria autora, mais adiante (p. 1464), esclarecerá: “Emprestamos da literatura o termo “leitura”, de modo que agora lemos filmes, lemos imagens" [N.T.]

\section{SPIVAK (2003). [N. T.]}

23. Conforme a definição da Encyclopaedia Britannica: “Os ‘Estudos de área' [consistem em] pesquisa social multidisciplinar focalizando regiões geográficas específicas, de áreas culturalmente definidas. As maiores comunidades de acadêmicos neste veio focalizam aquilo que é, em termos latos, definido como estudos sobre Ásia, África, América Latina ou sobre o Oriente Médio, ao lado de uma variedade de subcampos (Estudos do Sudeste Asiático, Estudos do Caribe etc.). Os programas [acadêmicos] voltados aos Estudos de Área baseiam-se, usualmente, em disciplinas como a ciência política, a sociologia, a etnologia, a geografia, a linguística, a literatura e os estudos culturais. Cf. https://www.britannica.com/ topic/area-studies. Acesso em: 1 ago. 2020. [Nota e tradução do tradutor]

24. 0 livro é a versão publicada das conferências organizadas sob os auspícios da Welleck Library Lectures in Critical Theory, apresentadas em 2000 na Universidade da Califórnia, Irvine.

25. Nós pensamos uma questão - nesta frase, ao dispensar as preposições "about" ou "of" na regência nominal do verbo "to think", a autora parece sublinhar a imanência entre o sujeito e o objeto do pensar, e, neste caso, ela estaria a privilegiar tal enunciado em vez de fórmula semelhante, mas na qual o verbo apareceria acompanhado da preposição "sobre": Nós pensamos sobre uma questão, frase na qual ficaria assinalada a precedência do sujeito no ato de pensar. [N.T.] 
26. Bracha Ettinger é artista, feminista, teórica da cultura e psicanalista. Um dos aspectos centrais de seu trabalho é a reflexão sobre a condição da arte de elaborar o trauma e de oferecer-se como testemunha. Sobre o conceito de autofragilização, ver o ETTINGER (2009, p. 9): “A autofragilização é arriscada e também dolorosa, porque estamos alcançando uma compaixão-para-além-da-empatia e uma com-paixão que não raro é difícil de tolerar no nível do indivíduo que busca segurança mental e precisar recuar de seus hábitos, internamente [...]". Ettinger é professora na Escola Europeia de Pós-Graduação. [Nota e tradução do tradutor]

27. Sobre a tese defendida por Ettinger a respeito da elaboração na arte, ver POLLOCK (2013b, pp. 1-36).

28. A expressão "liberal arts", nos Estados Unidos, refere-se (tal como aparece na formulação acima), ao ensino médio ou universitário - em oposição ao ensino técnico e profissionalizante - voltado às áreas de literatura, filosofia, ciências básicas, tendo por objetivo oferecer conhecimentos gerais e estimular a curiosidade intelectual dos estudantes. [N. T.]

29. As traduções da obra de Sigmund Freud pela Editora Companhia das Letras traduzem o termo unheimlich por "estranho" ou "inquietante", a o passo que as traduções mais recentes publicadas pela Editora Autêntica propõem traduzi-lo pelo neologismo "infamiliar". 0 ensaio de Freud “O estranho" aparece em FREUD (2010). [N. T.]

\section{PARKER; POLLOCK ([1981] 2013). [N.T.]}

31. Em certos períodos sem autoria ou mesmo sem o conceito de arte, tal como o formula a estética pós-século XVIII, a História da Arte tendeu, todavia, a organizar imagens sob uma projetada autoria, inventando Mestres. 0 exemplo é tomado de Frederick (Frigyes) Antal (aluno de Wölfflin e Max Dvorak); cf. ANTAL (1973).

32. Eu me baseei no estudo detalhado da estética de Freud realizado por Sarah Kofman (1988, esp. 1-21). Os comentários específicos sobre biográficos estão em "Leonardo da Vinci and a Memory of His Childhood" (FREUD, 1990, p. 223). 
34. Para a recepção crítica, ver BROUDE; GARRAD (1989) e POLLOCK ([1993] 1996). BUDER et. al. (2007) e REILLY; NOCHLIN (2007).

35. A título de um comentário à parte, devo dizer que em certa oc asião fiquei impressionada com o projeto de Marcia Pointon para um curso de primeiro ano panorâmico em História da Arte na Universidade de Manchester, focalizando centros de produção artística, e assim favorecendo uma modalidade de estudo que se localizava em situações à maneira de palimpsestos, sobrepondo tempo e espaço, contingência e possibilidade. Cidades ou comunidades pequenas, ou mesmo virtuais, ligadas por sistemas de comunicação, tornavamse centros auspiciosos para as práticas artísticas, a darem precedência ao acontecimento, ao que acontecera ali, com suas redes, em vez de tornar o que havia acontecido exemplar de uma narrativa espacial e temporal mais ampla: a história nacional, as escolas, ismos.

36. A autora se refere a suas divergências em relação a uma geração de historiadores da arte - entre eles T. J. Clark, Thomas Crow, Charles Harrison - que a partir da década de 1970 renovaram radicalmente o foco da história social da arte, agregando a seu método, tributário da teoria crítica, tanto a análise "interna" das obras como a contribuição interdisciplinar. 0 trecho sublinha em especial a posição crítica de Pollock em face do que julga ser a omissão de Clark em relação à contribuição do feminismo à renovação da disciplina, mormente no texto "The Conditions of Artistic Creation", originalmente publicado no Times Literary Supplement, em 1974. Disponível em: https://selvajournal.org/article/tj-clark-conditionsof-artistic-creation/. Acesso em: 21 jun. 2021. Para um aprofundamento da discussão, ver POLLOCK (2012a). [N.T.]

37. 0 enunciado melancólico “Wither Art History!" [Definhe, História da Arte!], arrematado por ponto de exclamação, perfaz aqui um corrosivo jogo de palavras com o mote da edição do Art Bulletin - Whither Art History? [Para onde vai a História da Arte?]-com o qual mantém semelhança fonética. [N. T.] 


\section{REFERÊNCIAS BIBLIOGRÁFICAS}

ANTAL, Frederick (Frigyes). Remarks on the Method of Art History. (1949). In ANTAL, Frederick. Classicism and Romanticism: With Other Studies in Art History. Londres: Harper and Row, 1973, pp. 175-189.

ARENDT, Hannah. As origens do totalitarismo. São Paulo: Companhia das Letras, 2012.

BARKER, Sheila. Women Artists and Their Contended Place in Public History, Art Herstory. 14 abr. 2020. Disponível em: https://artherstory.net/the-politicsof-exhibiting-female-old-masters/. Acesso em: 21 jun. 2021.

BAUMAN, Zygmunt. Modernidade líquida. Rio de Janeiro: Jorge Zahar Editor, 2001.

BENJAMIN, Walter. Pequena história da fotografia. In BENJAMIN, Walter. Magia e técnica, arte e política. Ensaios sobre literatura e história da cultura. São Paulo: Editora Brasiliense, 1987, vol. 1, pp. 91- 107.

BENJAMIN, Walter. Sobre o conceito de história. Edição crítica / org. e trad. Adalberto Müller e Márcio Seligmann-Silva. São Paulo: Alameda, 2020. 
BIDDICK, Kathleen. The Typological Imaginary: Circumcision, Technology, History. Filadélfia: University of Pennsylvania Press, 2003.

BROUDE, Norma; GARRAD, Mary. An Exchange on the Feminist Critique of Art History, Art Bulletin 71, no. 1 (março 1989), pp. 124-27.

BUDER, Cornelia et al. WACK! Art and the Feminist Revolution. Cambridge, Mass.: MIT Press, 2007.

DE LAURETIS, Teresa. Sexual Indifference and Lesbian Representation, Theatre Journal A0, n. 2, 1988, pp. 155-177, reimpresso em DE LAURETIS, Teresa. Figures of Resistance: Essays in Feminist Theory. Urbana: University of Illinois Press, 2007, pp. 48-71.

ETTINGER, Bracha. Fascinance and the Girl-to-m/Other Matrixial Feminine Difference. In POLLOCK, Griselda (ed.). Psychoanalysis and the Image: Transdisciplinary Perspectives. Boston: Blackwell, 2006, pp. 60-93.

ETTINGER, Bracha. Fragilization and Resistance. InETTINGER, Bracha. Fragilization and Resistance. Helsinque: Finnish Academy of Fine Arts, 2009, pp 97-134.

FEDERICI, Sylvia. Calibã e a bruxa: mulheres, corpo e acumulação primitiva. São Paulo: Editora Elefante, 2017. 
FOSTER, Hal. Postmodernism: A Preface. In FOSTER, Hal. The Anti- Aesthetic: Essays on Postmodern Culture. Port Townsend, Wash.: Bay Press, 1983, pp. IX-XVI.

FREUD, Sigmund. Femininity. (1933). In FREUD, Sigmund. New Introductory Lectures on Psychoanalysis, Penguin Freud Library, vol. 2. Harmondsworth, Reino Unido: Penguin Books, 1973, pp 145-169.

FREUD, Sigmund. The Uncanny ("Das Unheimliche"). (1919). In FREUD, Sigmund. Art and Literature, Penguin Freud Library, vol. 14. Harmondsworth, Reino Unido: Penguin Books, 1990, pp. 339-376.

FREUD, Sigmund. Leonardo da Vinci and a Memory of His Childhood. In FREUD, Sigmund. Art and Literature, Penguin Freud Library, vol. 11. Harmondsworth, Reino Unido: Penguin Books, 1990, pp. 63-137.

FREUD, Sigmund. Obras completas. Volume 14 - História de uma neurose infantil ('O Homem dos lobos"), Além do princípio do prazer e outros textos [1917-1920]. São Paulo: Companhia das Letras, 2010.

HARTMANN, Heidi. Towards a More Progressive Union, Capital and Class 3, n. 2, 1979, pp. 1-33.

HEMMINGS, Claire. Why Stories Matter: The Political Grammar of Feminist Theory. Durham, N.C.: Duke University Press, 2010. 
KOFMAN, Sarah. The Childhood of Art / trans. Winifred Woodhull. Nova York: Columbia University Press, 1988.

KRAUSS, Rosalind. The Optical Unconscious. Cambridge, Mass.: MIT Press, 1994.

LAPLANCHE, Jean. Notes on Afterwardness. In LAPLANCHE, Jean. Essays on Otherness. Londres: Routledge, 1999, pp. 260-265.

LAPLANCHE, Jean; PONTALIS, Jean-Bertrand Lefebvre. Vocabulário de psicanálise. São Paulo: Martins Fontes, 2016.

LEVY, Evonne. The Political Project of Wölfflin's Early Formalism, October, n. 139 (inverno 2012), pp. 39-58.

NELSON, Robert. The Map of Art History, Art Bulletin 79, n. 1, 1997, pp. 28-40.

NOCHLIN, Linda. Why have there been no great women artists. In NOCHLIN, Linda. Women, Art and Power and Other Essays. Boulder, Colorado: Westview Press, 1989, pp. 145-178.

PARKER, Rozsika; POLLOCK, Griselda. Old Mistresses: Women, Art and Ideology. Londres: Routledge, Kegan Paul, 1981; reimpressão, Londres: Pandora Books, 1993; Londres: I. B. Tauris, 2013. 
PETERSON, Thalia Gouma; MATHEWS, Patricia. The Feminist Critique of Art, Art Bulletin 63, n. 9, 1987, pp. 326-57.

POLLOCK, Griselda. Artists, Mythologies and Media: Genius, Madness and Art History, Screen 21, n. 3, 1980, pp. 57-96.

POLLOCK, Griselda. Avant-garde Gender and the Colour of Art History. Londres: Thames and Hudson, 1993.

POLLOCK, Griselda. Generations and Geographies: The Politics of Theory and the Histories of Art, Genders, n. 17 (outono 1993), pp. 97-120, reimpresso em POLLOCK, Griselda (ed). Generations and Geographies in the Visual Arts: Feminist Readings. Londres: Roudedge, 1996, pp. 3-21.

POLLOCK, Griselda. Agency and the Avant-Garde: Studies in Authorship by Way of Van Gogh, Block 15, 1989, pp. 5-15, reimpresso in ORTON, Fred; POLLOCK, Griselda. Avant-Gardes and Partisans Reviewed. Manchester, Reino Unido.: Manchester University Press, 1996, 315-4.

POLLOCK, Griselda. Differencing the Canon: Feminist Desire and the Writing of Art's Histories. Londres: Roudedge, 1999.

POLLOCK, Griselda. Vision and Difference: Feminism, Femininities and the Histories of Art (1988; edição clássica com novo prefácio). Londres: Routledge, 2003. 
POLLOCK, Griselda. Encounters in the Virtual Feminist Museum: Time, Space and the Archive. Londres: Routledge, 2007.

POLLOCK, Griselda. Unexpected Turns: The Aesthetic, the Pathetic and the Adversarial in the Longue Durée of Art's Histories, Journal of Art Historiography 7, dezembro 2012a.

POLLOCK, Griselda. Saying No! Profligacy versus Austerity, or Metaphor against Model in Justifying the Arts and Humanities in the Contemporary University, European Journal of Popular Cultured, n. 1, 2012b, pp. 87-104.

POLLOCK, Griselda. Aby Warburg and 'Thinking Jewish' in Modernity. In PICARD, Jacques et. al. Thinking Jewish Modernity. Basiléia: University of Basel Press, 2013a.

POLLOCK, Griselda. After-Affects/ After-images: Trauma and Aesthetic Transformation in the Virtual Feminist Museum. Manchester, Reino Unido: Manchester University Press, 2013b.

POLLOCK, Griselda. From Horrorism to Compassion: Refacing Medusan Otherness with Adriana Cavarero and Bracha Ettinger. In POLLOCK, Griselda (ed.). Visual Politics of Psychoanalysis: Art \& the Image in Post-Traumatic Cultures. Londres: I. B. Tauris, 2013c, pp. 159-198. 
RAMPLEY, Matthew et al. Art History and Visual Studies in Europe: Transnational Discourses and National Frameworks. Leiden: Brill, 2012.

REILLY, Maura; NOCHLIN, Linda. Global Feminisms: New Directions in Contemporary Art. Nova York: Merrell, 2007.

SCHADE, Sigrid. Schadenzauber und die Magie des Körpers: Hexenbilder der frühen Neuzeit. Worms: Werner, 1983.

SCHAPIRO, Meyer.Anatureza da arte abstrata. In SCHAPIRO, Meyer. A arte moderna: séculos XIX e XX. Ensaios escolhidos. São Paulo: EDUSP, 2010, pp. 251-276.

SILVERMAN, Kaja. The Fantasy of the Maternal Voice. In SILVERMAN, Kaja. The Acoustic Mirror: The Female Voice in Psychoanlaysis and Cinema. Bloomington: Indiana University Press, 1988, pp. 119-124.

SILVERMAN, Max; POLLOCK, Griselda (eds.). Concentrationary Imaginaries: Tracing Totalitarian Violence in Popular Culture. Londres, Nova York: I.B. Tauris, 2015.

SPIVAK, Gayatri Chakravorty. Death of a Discipline. Nova York: Columbia University Press, 2003. 
Griselda Pollock é professora de Histórias Sociais e Críticas da Arte e diretora do Centro de Análise Cultural, Teoria e História, na Universidade de Leeds, na Inglaterra.

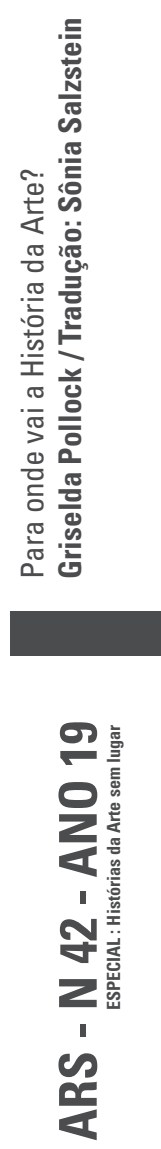

1520 
Sônia Salzstein é Professora Titular de História da Arte Moderna e Contemporânea e de Teoria da Arte na ECA/USP e no Programa de Pós-Graduação em Artes Visuais na mesma instituição. Na universidade, organizou cursos e simpósios internacionais, entre os quais o "Simpósio Internacional Picasso: Outros critérios", e cursos de curta duração. Publicou diversos estudos sobre arte moderna e arte e cultura contemporâneas em publicações como Manet/Georges Bataille (2020); Picassian Signs in Transit: Brazilian Art in The 20 ${ }^{\text {th }}$ Century (2020); Pop Art and Vernacular Culture (2007), Alfredo Volpi (2000), Mira Schendel/No vazio do mundo (1997), além de ter organizado Diálogos com Iberê Camargo (2003) e a coletânea Matisse/Imaginação, erotismo, visão decorativa (2009). Entre 2006 e 2010, trabalhou como editora na Cosac Naify, onde dirigiu coleção dedicada à arte moderna e contemporânea. É editora da revista Ars, do Programa de Pós-Graduação em Artes Visuais da ECA-USP. 